\title{
UCRL-TR-217159
}

LAW RENCE LIVERMORE N A T IO N A L LABORATORY
Environmental transport and fate of endocrine disruptors from non-potable reuse of municipal wastewater

B. Hudson, H. Beller, C. M. Bartel, S. Kane, C. Campbell, A. Grayson, N. Liu, S. Burastero

November 16, 2005 
This document was prepared as an account of work sponsored by an agency of the United States Government. Neither the United States Government nor the University of California nor any of their employees, makes any warranty, express or implied, or assumes any legal liability or responsibility for the accuracy, completeness, or usefulness of any information, apparatus, product, or process disclosed, or represents that its use would not infringe privately owned rights. Reference herein to any specific commercial product, process, or service by trade name, trademark, manufacturer, or otherwise, does not necessarily constitute or imply its endorsement, recommendation, or favoring by the United States Government or the University of California. The views and opinions of authors expressed herein do not necessarily state or reflect those of the United States Government or the University of California, and shall not be used for advertising or product endorsement purposes.

This work was performed under the auspices of the U.S. Department of Energy by University of California, Lawrence Livermore National Laboratory under Contract W-7405-Eng-48. 


\section{Environmental transport and fate of endocrine disruptors from non-potable reuse of municipal wastewater}

\section{Final Report for 03-ERD-065}

Bryant Hudson ${ }^{1}$, Harry Beller ${ }^{2}$, Cheryl Moody Bartel ${ }^{1}$, Staci Kane ${ }^{2}$, Chris Campbell ${ }^{3}$, Allen Grayson ${ }^{3}$, Nan Liu ${ }^{4}$, and Stephen Burastero ${ }^{5}$

1. Chemical Biology and Nuclear Science Division, CMS

2. Environmental Restoration, EPD, SEP

3. Water Guidance and Monitoring Group, EPD, SEP

${ }^{4}$ Biosciences Directorate

${ }^{5 .}$ Health Services Department, SEP 


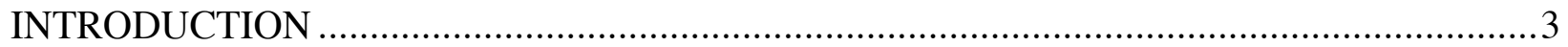

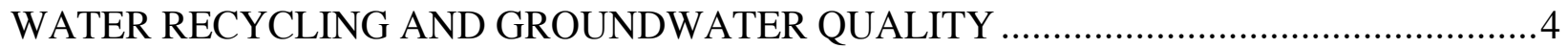

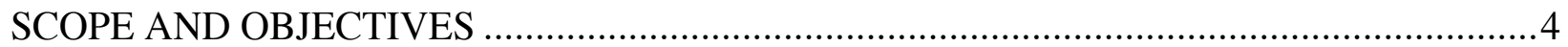

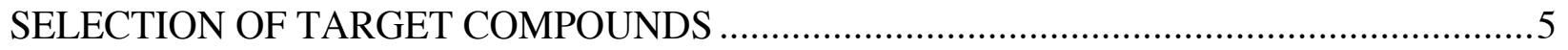

ALKYLPHENOL ETHOXYLATE METABOLITES ………..........................................

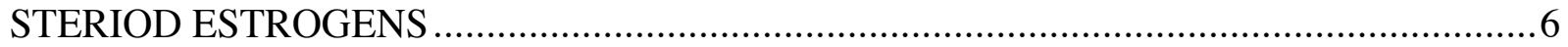

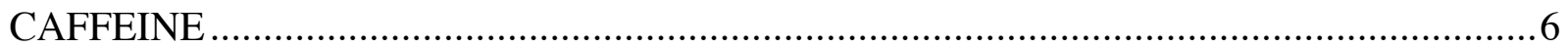

DESCRIPTION OF STUDY SITE: LAS POSITAS GOLF COURSE (LPGC) .........................

TRITIUM AS A VALUABLE TRACER AT THE LPGC...............................................

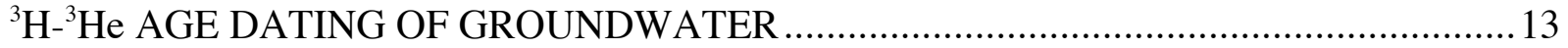

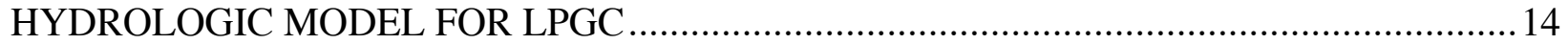

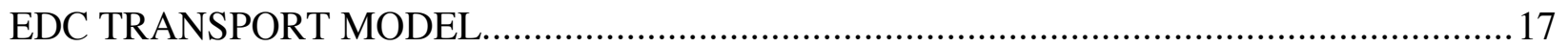

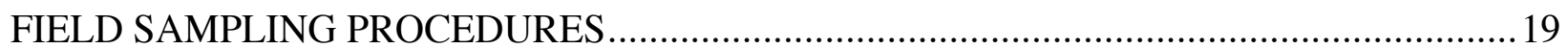

DEVELOPMENT OF LC/MS/MS METHODS FOR TARGET COMPOUNDS......................20

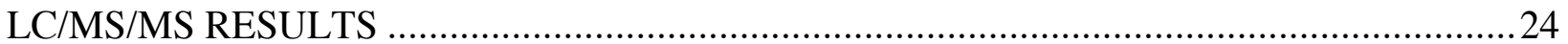

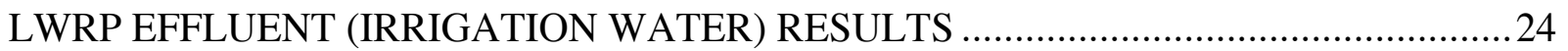

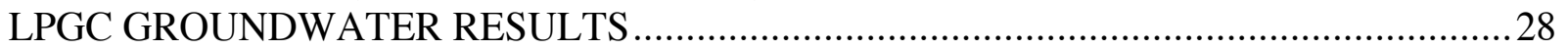

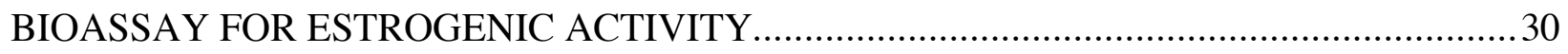

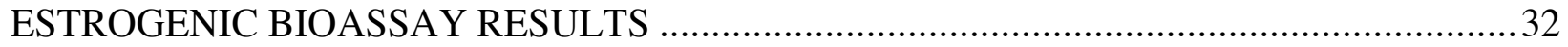

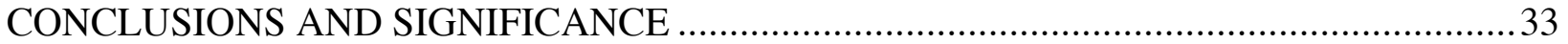

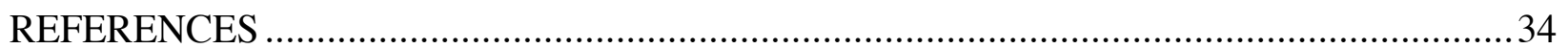




\section{INTRODUCTION}

Endocrine Disrupting Compounds (EDCs) are a group of hormonally active agents of emerging concern to the regulatory and engineering community, particularly among potable water and wastewater reuse agencies (a primary source for EDCs is municipal wastewater treatment facilities). EDCs are natural and synthetic compounds with the potential to elicit negative effects on endocrine systems of humans and wildlife by either stimulating or inhibiting normal hormonal activity. A wide range of chemical compounds have been identified that induce estrogen-like responses, including natural and synthetic hormones, pharmaceuticals, pesticides, industrial chemicals, and heavy metals (NRC, 1999; Giesy et al., 2002). The U.S. Environmental Protection Agency (US EPA) defines an EDC as:

an exogenous agent that interferes with the synthesis, secretion, transport, binding, action, or elimination of natural hormones in the body that are responsible for the maintenance of homeostasis, reproduction, development, and/or behavior. (US EPA, 1997)

This broad class of chemicals includes both natural and synthetic estrogens (e.g., xenoestrogens and pseudoestrogens). Specific examples of estrogenic EDCs include: pesticides like atrazine, dieldrin, and toxaphene (Hayes et al., 2002; Ramamoorthy et al., 1997; Arnold et al. 1996a); surfactants such as alkyphenol ethoxylates and their metabolic products (Folmar et al., 2002; Legler et al., 2002a; Ying et al., 2002); natural hormones and pharmaceutical estrogens such as 17־-estradiol and 17】-ethynylestradiol (Legler et al., 2002a; Folmar et al., 2000); phytoestrogens including isoflavonoids and coumestrol (Bacaloni et al., 2005; Stopper et al., 2005); and other industrial compounds like PCBs, bisphenol A, and chlorinated dibenzodioxins (Howdeshell et al., 1999; Ramamoorthy et al., 1997; Mocarelli et al., 1996).

A variety of these compounds have been detected in the environment, with over 60 compounds currently identified (e.g., Kolpin et al., 2002, NRC, 1999). Given that many of the EDCs identified have the potential to cause an estrogenic response at very low concentrations (parts per billion to parts per trillion) it is cause for concern that measurable concentrations of many of the EDCs mentioned above have been found in wastewater, surface waters, sediments, groundwater, and even drinking water (Petrovic et al., 2004; Benfenati et al., 2003, Petrovic et al., 2003; Snyder et al., 2003). Wastewater treatment plants have been studied as a major source for EDCs (Westerhoff et al., 2005; Snyder et al., 2003; Kolpin et al., 2002; Legler et al., 2002a). Various compounds have been reported to have endocrine-disrupting effects on fish and wildlife, as detailed elsewhere (Johnson et al., 1998; Fry, 1995; Guillette et al., 1994; McLachlan, 1985; Fry and Toone, 1981; Colborn et al., 1993). At the same time, human exposure to EDCs is a critical concern with unknown long-term impacts. There is concern with regard to potential human health effects of EDCs because of their environmental persistence, tendency to accumulate in adipose tissue, and potential for additive toxicity when multiple EDCs are present.

In light of these serious potential impacts to receptor populations, the US EPA continues to compile, evaluate, and update the current state of knowledge on EDCs and has initiated an EDC screening program (http://www.epa.gov/scipoly/oscpendo/index.htm). Recent advances in analytical chemistry (in particular, liquid chromatography/tandem mass spectrometry, or LC/MS/MS) as well as widespread interest in EDCs has promoted the development of advanced 
analytical methods, including gas chromatography/tandem mass spectrometry (GC/MS/MS) and LC/MS/MS (e.g., Ternes et al., 2004; Petrovic et al., 2002; Huang and Sedlak, 2001; Petrovic and Barceló, 2000; Fan et al., 2005; Heisterkamp et al., 2004; Zhang et al., 2004; Wozei, 2004). These analytical techniques provide excellent sensitivity and precision for monitoring EDCs. Although concentration measurements are necessary in studies of EDC fate and transport in the environment, they do not provide direct data on estrogenic effects or synergistic effects from multiple EDCs. Furthermore, since these advanced techniques target specific EDCs, the target compounds must be EDCs that have already been identified. Therefore, as a complement to highly sensitive and specific chemical analysis of known EDCs, bioassays are needed to characterize total estrogenic potency in environmental samples.

\section{WATER RECYCLING AND GROUNDWATER QUALITY}

Water is a limited resource in many regions of the world and recycling of wastewater is an attractive option for enhancing supply. Artificially recharging recycled (reclaimed) wastewater into groundwater aquifers has become an important management strategy for increasing the potable water supply in many regions. Projects designed to treat wastewater to very high purity standards for indirect potable reuse have met with significant public opposition in most areas in the United States. These projects are often labeled "toilet to tap" by project opponents. At the same time, water-recycling projects for non-potable reuse, such as landscape irrigation, that use less rigorously treated water have been widely accepted and implemented. In non-potable reuse projects, wastewater is filtered and disinfected, but many dissolved compounds are not removed. Issues related to contaminants covered by primary and secondary drinking water standards are well understood; however, there are a variety of trace organic compounds, such as pharmaceuticals and EDCs, whose impacts are largely unknown.

\section{SCOPE AND OBJECTIVES}

This project was designed to investigate the important but virtually unstudied topic of the subsurface transport and fate of EDCs when treated wastewater is used for landscape irrigation (non-potable water reuse). Although potable water reuse was outside the scope of this project, the investigation clearly has relevance to such water recycling practices.

The target compounds, which are discussed in the following section and include EDCs such as 4-nonylphenol (NP) and 17 7 -estradiol, were studied not only because of their potential estrogenic effects on receptors but also because they can be useful as tracers of wastewater residue in groundwater. Since the compounds were expected to occur at very low (part per trillion) concentrations in groundwater, highly selective and sensitive analytical techniques had to be developed for their analysis. This project assessed the distributions of these compounds in wastewater effluents and groundwater, and examined their fate in laboratory soil columns simulating the infiltration of treated wastewater into an aquifer (e.g., as could occur during irrigation of a golf course or park with nonpotable treated water). Bioassays were used to determine the estrogenic activity present in effluents and groundwater, and the results were correlated with those from chemical analysis. In vitro assays for estrogenic activity were employed to provide an integrated measure of estrogenic potency of environmental samples without requiring knowledge or measurement of all bioactive compounds in the samples. 
For this project, the Las Positas Golf Course (LPGC) in the City of Livermore provided an ideal setting. Since 1978, irrigation of this area with treated wastewater has dominated the overall water budget. For a variety of reasons, a group of 10 monitoring wells were installed to evaluate wastewater impacts on the local groundwater. Additionally, these wells were regularly monitored for tritium $\left({ }^{3} \mathrm{H}\right)$. Overall volumes of irrigation water have been recorded along with total flows through the Livermore Water Reclamation Plant (LWRP). The Environmental Protection Department at LLNL has carefully monitored ${ }^{3} \mathrm{H}$ effluent leaving the laboratory for many years. For two years preceding the initiation of this project, Grayson and Hudson, working with LWRP staff, had demonstrated that these data could be used to accurately calculate the ${ }^{3} \mathrm{H}$ concentration in the applied irrigation water as a function of time. This was accomplished by performing two carefully monitored tritium releases from LLNL and following the ${ }^{3} \mathrm{H}$ through the LWRP. Combining these data with our ability to age-date groundwater using the ${ }^{3} \mathrm{H}-{ }^{3} \mathrm{He}$ agedating technique, it was possible determine both the age and the degree of dilution from other water sources. This information was critical in the evaluation of observed concentrations of trace organic compounds from wastewater.

The project included the following tasks:

1. Develop a conceptual model for Las Positas Golf Course (LPGC) irrigation that integrates existing meteorological, hydrologic, and environmental monitoring data.

2. Develop analytical methods (involving solid-phase extraction and isotope dilution LC/MS/MS) for the specific and sensitive measurement of target EDCs.

3. Develop a bioassay for estrogenic activity for application to effluent and groundwater samples.

4. Perform detailed hydrological evaluation of groundwater taken from LPGC.

5. Characterize the source term for target EDCs in wastewater.

6. Evaluate the utility of EDCs as source tracers for groundwater contamination.

\section{SELECTION OF TARGET COMPOUNDS}

\section{ALKYLPHENOL ETHOXYLATE METABOLITES}

Alkylphenol ethoxylates (APEOs), a class of nonionic surfactants, and their metabolites are the most prominent group of EDCs identified in wastewater and treated wastewater. In particular, nonylphenol ethoxylates (NPEOs) constitute the largest subgroup of the APEOs (encompassing more than $80 \%$ of the world market). Municipal wastewater treatment (including biological treatment) tends to result in efficient elimination of the parent APEOs but formation of biologically refractory metabolites including the following: alkylphenol mono- and diethoxylates (i.e., $n=1$ or 2 in Figure 1), alkylphenol carboxylic acids (e.g., NP1EC and NP2EC; Figure 1), and 4-nonylphenol (NP; Figure 1) (Ahel et al., 1994). NP is a metabolite and representative of 
the APEO (and specifically, NPEO) class of endocrine disruptors (Figure 1) that has recently been reported to have a wide distribution in surface waters (Kolpin et al., 2002) and is well documented to be present in effluents of wastewater treatment plants (WWTP) at $\square \mathrm{g} / \mathrm{L}$ concentrations (e.g., Johnson and Sumpter, 2001). The hormonal and toxicological properties of NP have resulted in the banning of NPEOs for domestic and industrial use in many parts of Europe (Blackburn and Waldock, 1995).

Considering that tertiary-treated sewage effluent is the source of irrigation water at the LPGC, we considered NP to be among the most likely EDCs to be found in the underlying groundwater. In addition to NP, we also considered that the monocarboxy APEO metabolites known as APEC, which are NP precursors (Figure 1), could also be present in groundwater in the irrigated zone. APECs have been observed at considerably (e.g., ten-fold) higher concentrations in WWTP effluents than NP (Johnson and Sumpter, 2001). Notably, since APECs have carboxyl groups that are likely to be ionized in a groundwater environment at circumneutral $\mathrm{pH}$, they would be expected to be more soluble and mobile in groundwater than NP.

\section{STERIOD ESTROGENS}

Estrogenic steroid hormones such as estrone $\left(\mathrm{E}_{1}\right)$ and 17ฤ-estradiol $\left(\mathrm{E}_{2}\right)$ (Figure 1) are significant contributors to the total estrogenic activity observed in wastewater (Johnson and Sumpter, 2001). In particular, estrone-3-sulfate $\left(E_{1}-3 S\right.$; Figure 1$)$ is a sulfonide conjugate of estrone that researchers have suggested may survive sewage treatment systems and be transmitted into receiving waters (Johnson and Sumpter, 2001). All three of these compounds were considered as wastewater trace components that could potentially be transported into underlying groundwater as a result of prolonged irrigation with treated wastewater.

\section{CAFFEINE}

Although not an EDC, caffeine was chosen as a target compound for this study because it is a unique indicator of human waste that has been widely detected in surface waters and groundwater, and its presence in environmental samples has specifically been linked to WWTP effluent (Seiler et al., 1999 and references therein; Kolpin et al., 2002; Standley et al., 2000). Although it is relatively biodegradable (considerably more so than NP), caffeine is nonetheless observed in the environment near WWTP sources and was thus considered a promising wastewater indicator in this study. 


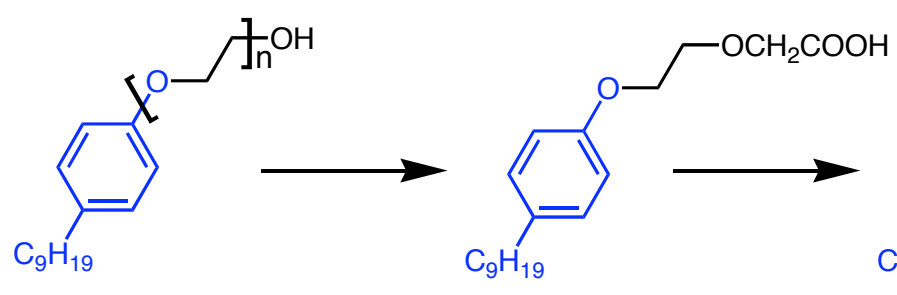

APEOS (specifically, NPEOs)<smiles>CC12CCC3c4ccc(O)cc4CCC3C1CCC2O</smiles>

Estradiol<smiles>CC12CCC3c4ccc(O)cc4CCC3C1CCC2=O</smiles>

Estrone<smiles>CC12CCC3c4ccc(S(=O)(=O)O)cc4CCC3C1CCC2=O</smiles>

Estrone-3-sulfate ( $\left.E_{1}-3 S\right)$

Figure 1. Structures of EDC-related chemicals addressed in this study. The value of " $n$ " for APEOs is 3 to 20. Not all metabolites in the biodegradation of NPEOs to NP are shown, but the relationships among APEOs, APECs, and NP can be ascertained from the figure. 


\section{DESCRIPTION OF STUDY SITE: LAS POSITAS GOLF COURSE (LPGC)}

The Las Positas Golf Course (LPGC) in Livermore, California (Figure 2) provides a unique opportunity to investigate the transport and impact of wastewater compounds on groundwater resources. Recycled water has been used since 1978 to provide turf irrigation for the golf course in what is a relatively arid climate. Average yearly precipitation at LPGC is approximately 15" per year and occurs primarily in the winter (Figure 3). Irrigation is necessary in the summer and approximately 36" per year of recycled water is required to maintain vegetation at the LPGC.

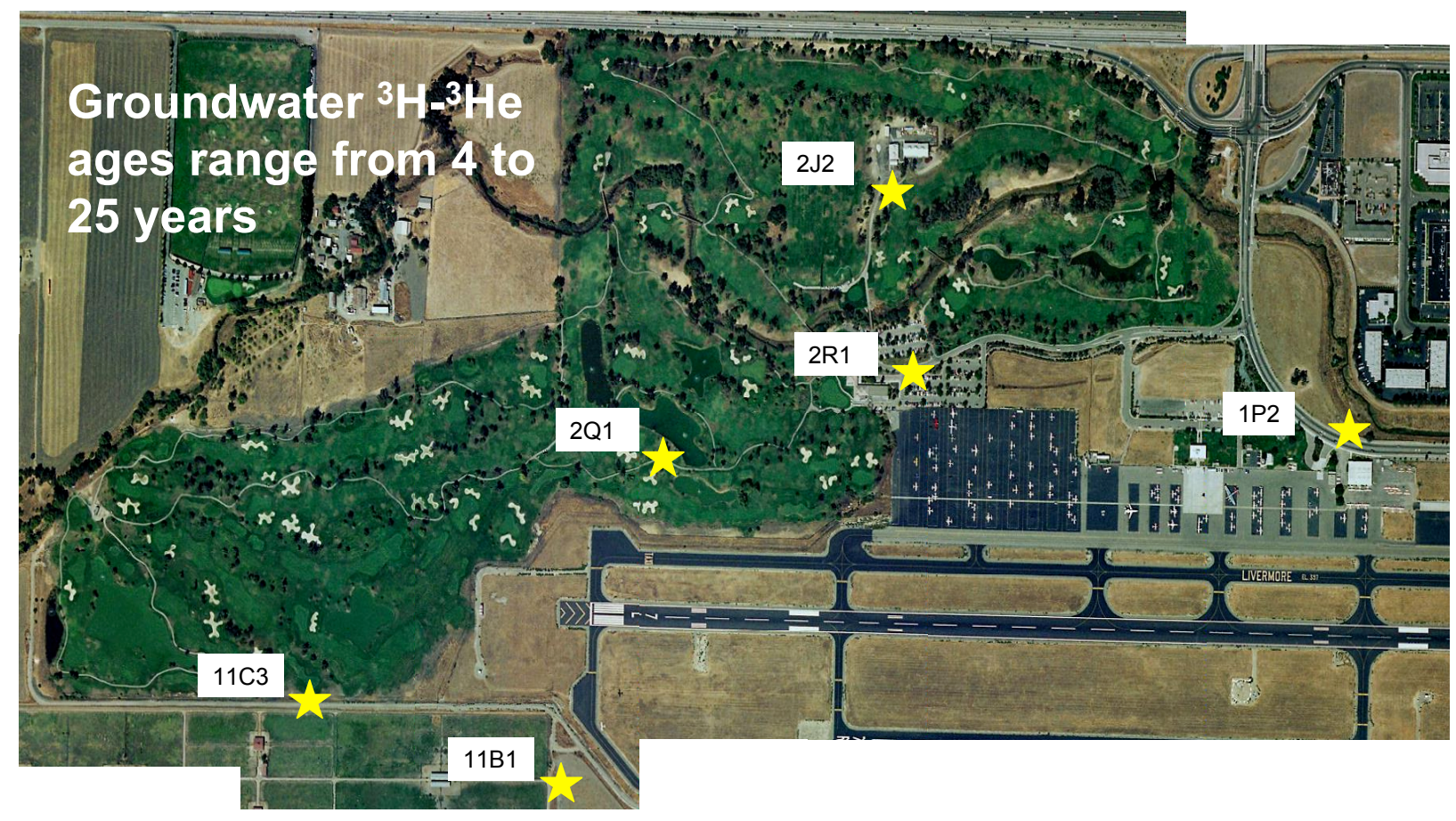

Figure 2. Aerial view of study site with monitoring well locations highlighted. 


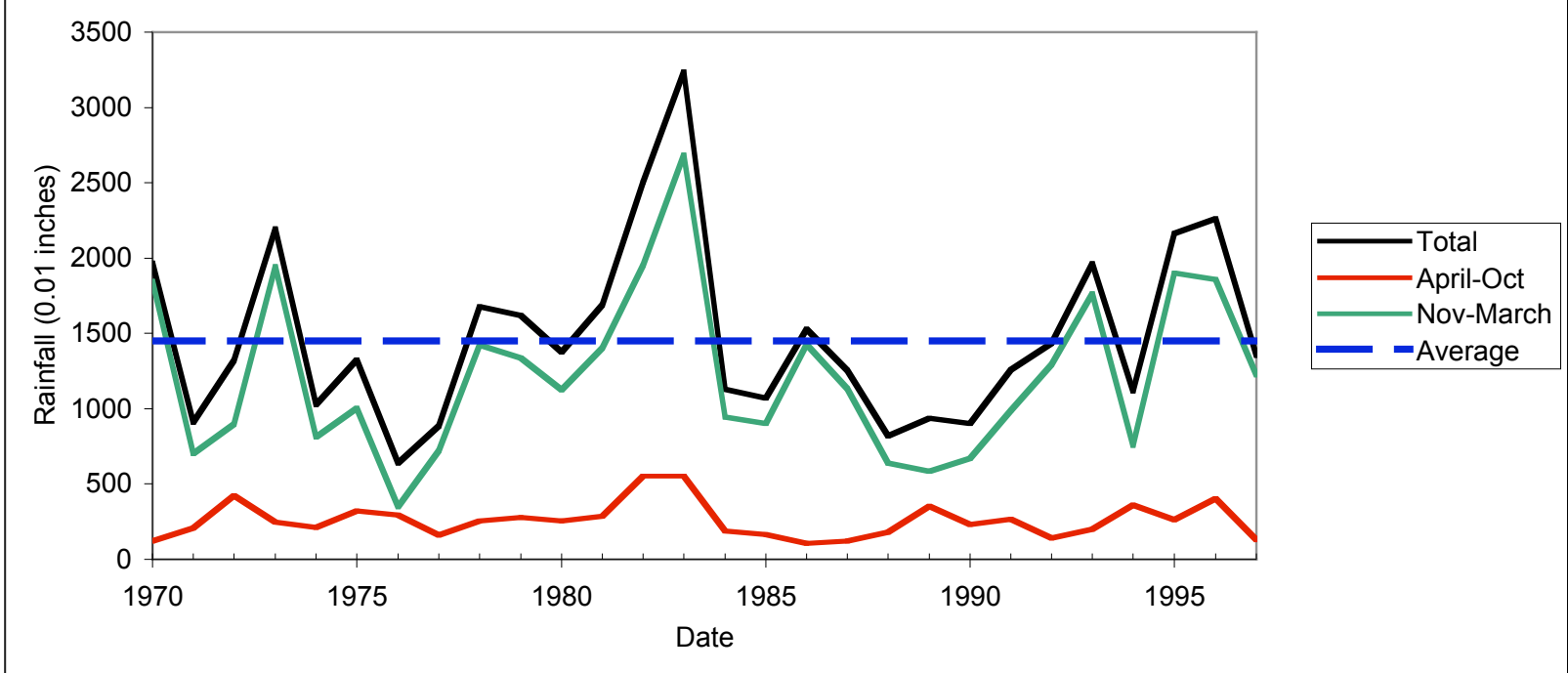

Figure 3. Rainfall trends for the study area since 1970.

\section{TRITIUM AS A VALUABLE TRACER AT THE LPGC}

Tritium is a radioactive isotope of hydrogen $\left({ }^{3} \mathrm{H}\right.$, half-life $=12.3$ years $)$ that is naturally present in the environment due to interactions of cosmic rays with the atmosphere. Tritium is also present due to man-made sources, most notably nuclear weapons. Nuclear weapons testing in the 1960s increased the tritium concentration in precipitation by more than a factor of 1000 over natural levels in 1963. Tritium has been routinely used at LLNL since the beginning of the laboratory in 1952. While tritium is radioactive, the nuclear decay energy is quite low. Tritium decays by beta emission, that is, an energetic electron is emitted when tritium transforms to stable ${ }^{3} \mathrm{He}$. The average electron energy in $7 \mathrm{keV}$ can only penetrate $1 \times 10^{-6} \mathrm{~m}$ of water before stopping. This decay energy is so low that only very sensitive methods can detect its presence.

Because of tritium's low decay energy, this radioactive isotope has found significant use in consumer products. Luminous watch dials and building signs using tritium are quite common. In the course of LLNL's national security mission, tritium has been used in a variety of programs and some tritium is released from the laboratory to the sanitary sewer system. Such releases are regulated and carefully monitored. The typical annual release in recent years equals the amount of tritium contained in one wrist watch. While this is a very low level, methods have been developed at LLNL and other laboratories to detect tritium at extraordinarily low levels.

Since the release of radioactive materials into the environment is a source of community concern, LLNL developed detailed and aggressive environmental monitoring programs to monitor radioactive material releases. It is the combination of the tritium releases combined with detailed monitoring programs that makes the LPGC interesting. It is appropriate to note that the release of trace amounts of tritium is not unique to LLNL. Many large cities have far larger annual tritium releases to their wastewater systems. Again, these releases are carefully regulated, but do not receive the level of monitoring that LLNL has put in place. 
In the mid 1970s, the city of Livermore began a program to recycle wastewater and use the water to irrigate the LPGC. The U.S. Geological Survey installed several groundwater monitoring wells nearby the LPGC and LLNL and recognized the opportunity to use these wells for tritium monitoring.

The monitoring results show the clear connection between the application of recycled water and the local shallow groundwater. The overall trend in tritium releases from LLNL is decreasing. While the LLNL tritium releases have always been well below regulatory limits, the general goal of programs using tritium at LLNL has been to reduce releases as can be reasonably achieved. We see in Figure 4 a close match between the monitoring wells and the recycled water. As will be discussed, the relationship between the tritium concentration observed in the monitoring wells and the irrigation water is relatively complex, nevertheless, the presence of the tritium tracer provides a clear indication of the connection.

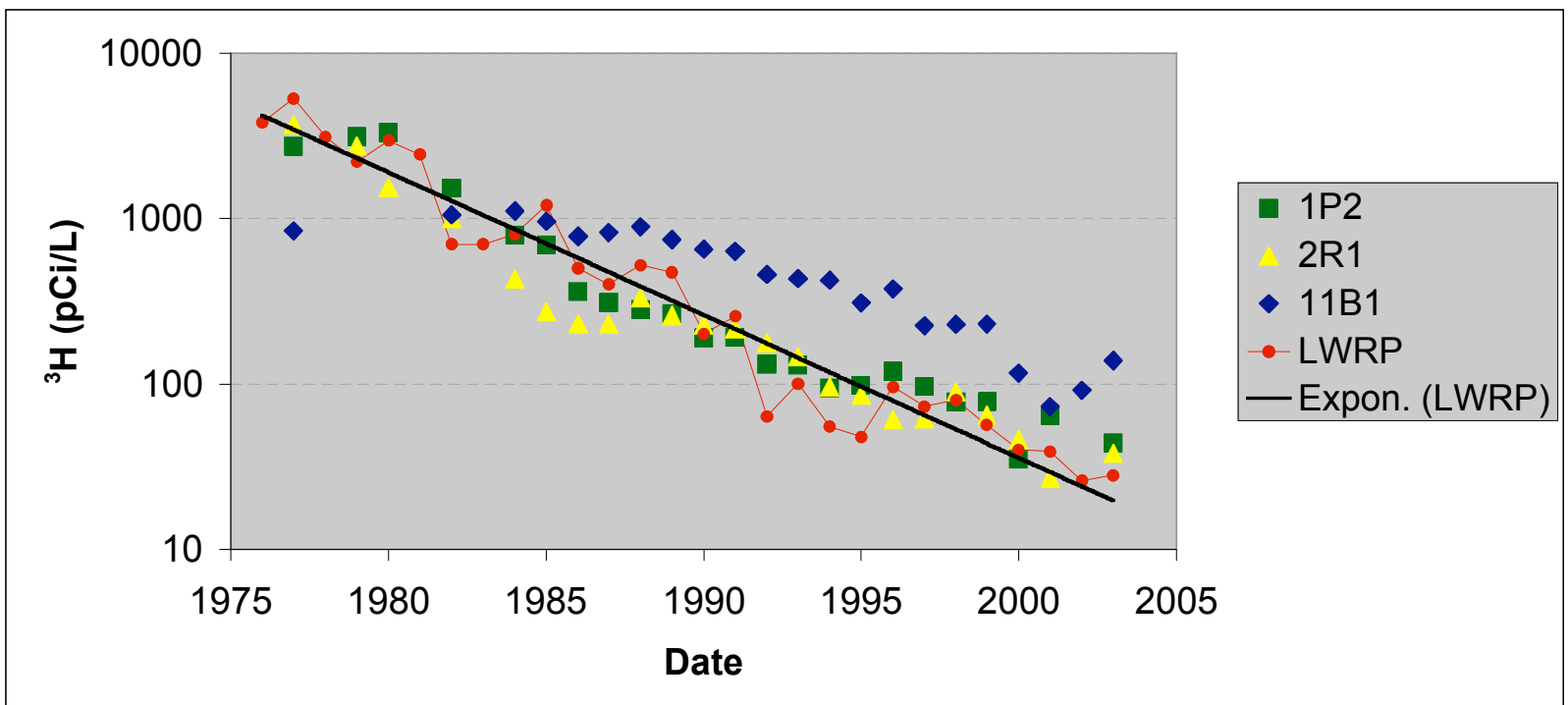

Figure 4. Time trends for tritium concentrations in LWRP effluent and selected monitoring wells.

\section{ISOTOPIC DATA FOR LPGC GROUNDWATER}

We have selected five groundwater monitoring wells for detailed analysis of environmental isotopes and wastewater compounds and the well characteristics are provided in Table 1 . Three of these wells $(2 \mathrm{~J} 2,2 \mathrm{Q} 1,11 \mathrm{C} 3)$ were recently constructed by the local water agency (Alameda County Zone 7) for this project. Table 2 gives sampling dates and water chemistry data for these wells. The major ions for these samples are sodium and chloride as might be expected for groundwater with a significant wastewater component. 
Table 1. Description of LPGC wells.

\begin{tabular}{|c|c|c|c|c|c|c|}
\hline State Well ID & Elevation & Latitude & Longitude & $\begin{array}{c}\text { Total Well } \\
\text { Depth }\end{array}$ & $\begin{array}{c}\text { Perforation } \\
\text { top }\end{array}$ & $\begin{array}{c}\text { Perforation } \\
\text { bottom }\end{array}$ \\
\hline & (ft) & (decimal degrees) & (decimal degrees) & (ft bgs) & (ft bgs) & (ft bgs) \\
\hline 03S/01E-01P02 M & 357 & 37.6961 & -121.8159 & 50 & 40 & 45 \\
03S/01E-02J02 M & 353 & 37.6992 & -121.8243 & 41 & 31 & 41 \\
03S/01E-02Q01 M & 353 & 37.6955 & -121.8293 & 45 & 35 & 45 \\
03S/01E-02R01 M & 363 & 37.6968 & -121.8238 & 33 & 21 & 26 \\
03S/01E-11C03 M & 347 & 37.6929 & -121.8342 & 60 & 55 & 60 \\
\hline
\end{tabular}

bgs - below ground surface

Table 2. Conventional water chemistry data for LPGC groundwater.

\begin{tabular}{|c|c|c|c|c|c|c|c|c|c|c|c|c|}
\hline State Well ID & \begin{tabular}{|c|}
$\begin{array}{c}\text { Collection } \\
\text { date }\end{array}$ \\
\end{tabular} & Temp & \begin{tabular}{|l|} 
Conductivity \\
\end{tabular} & $\mathrm{pH}$ & Fluoride & Chloride & Nitrate & Sulfate & Sodium & Potassium & \begin{tabular}{|l|} 
Magnesium \\
\end{tabular} & Calcium \\
\hline & & $\left({ }^{\circ} \mathrm{C}\right)$ & $(\square S)$ & & $(\mathrm{mg} / \mathrm{L})$ & $(\mathrm{mg} / \mathrm{L})$ & $(\mathrm{mg} / \mathrm{L})$ & $(\mathrm{mg} / \mathrm{L})$ & $(\mathrm{mg} / \mathrm{L})$ & $(\mathrm{mg} / \mathrm{L})$ & $(\mathrm{mg} / \mathrm{L})$ & \\
\hline 03S/01E-01P02 M & 19-Jun-03 & 19.2 & 1440 & 7.41 & & 218 & 8.4 & 96 & & & & \\
\hline 03S/01E-01P02 M & 26-Aug-03 & 20.7 & 1455 & 8.00 & 0.34 & 220 & 8.2 & 80 & 171 & 1.8 & 28 & 64 \\
\hline 03S/01E-01P02 M & 18-Mar-04 & 19.7 & 1580 & 7.50 & 0.34 & 166 & 5.7 & 97 & 171 & 1.7 & 39 & 22 \\
\hline 03S/01E-01P02 M & 23-Jun-04 & 19.5 & 1590 & 7.44 & 0.39 & 217 & 6.9 & 95 & 198 & 2.0 & 45 & 62 \\
\hline 03S/01E-02J02 M & 26-Aug-03 & 18.8 & 3280 & 7.20 & 0.19 & 694 & 8.8 & 171 & 425 & 2.4 & 44 & 153 \\
\hline 03S/01E-02J02 M & 18-Mar-04 & 20.2 & 3160 & 7.20 & 0.20 & 455 & 6.5 & 190 & 385 & 1.6 & 61 & 37 \\
\hline 03S/01E-02Q01 M & 26-Aug-03 & & 2200 & 7.10 & 0.29 & 390 & 23.3 & 110 & 267 & 2.4 & 34 & 81 \\
\hline 03S/01E-02Q01 M & 18-Mar-04 & 18.7 & 2450 & 7.40 & 0.30 & 301 & 19.6 & 135 & 229 & 1.8 & & 101 \\
\hline 03S/01E-02R01 M & 26-Aug-03 & 19.6 & 1497 & 7.79 & 0.32 & 186 & 16.6 & 70 & 199 & 2.0 & 37 & 39 \\
\hline 03S/01E-02R01 M & 18-Mar-04 & 20.7 & 1540 & 7.20 & 0.30 & 117 & 9.3 & 68 & 165 & 1.3 & 43 & 19 \\
\hline 03S/01E-11C03 M & 18-Mar-04 & 18.7 & 2080 & 7.30 & 0.25 & 186 & 18.2 & 108 & 213 & 1.6 & 54 & 19 \\
\hline
\end{tabular}

We examined the isotopic composition of $\mathrm{H}, \mathrm{C}, \mathrm{N}$, and $\mathrm{O}$ to help constrain the relationship between the sampled groundwater and its potential sources; the data are summarized in Table 3. The stable isotopes of $\mathrm{H}$ and $\mathrm{O}$ can potentially be used to identify contributions from local precipitation and wastewater from the LWRP. Most of the water used in the Livermore Valley comes from the State Water Project and consists of precipitation that fell in the Sierra Nevada at high altitude. This water is significantly depleted in the heavier stable isotopes of $\mathrm{H}$ and $\mathrm{O}$ when compared to local precipitation in the Livermore Valley. The isotopic composition is reported in terms of its deviation (in parts per thousand) from a known standard value:

$$
\begin{aligned}
& \left.\square^{18} \mathrm{O}=1000 *\left(\left({ }^{18} \mathrm{O} /{ }^{16} \mathrm{O}\right)_{\text {sample }} /\left({ }^{18} \mathrm{O} /{ }^{16} \mathrm{O}\right)_{\text {SMOw }}\right)-1\right) \\
& \left.\square^{2} \mathrm{H}=1000 *\left(\left({ }^{2} \mathrm{H} /{ }^{1} \mathrm{H}\right)_{\text {sample }} /\left({ }^{2} \mathrm{H} /{ }^{1} \mathrm{H}\right)_{\text {SMOw }}\right)-1\right)
\end{aligned}
$$

where the standard is Standard Mean Ocean Water (SMOW). In these units, $\square^{18} \mathrm{O}$ is about -7.5 for precipitation and -9.5 for wastewater from the LWRP. The data for $\mathrm{O}$ and $\mathrm{H}$ stable isotopes is shown in Figure 5. Evaporation of the applied irrigation water also produces shifts in the $\mathrm{H}$ and $\mathrm{O}$ isotopic compositions. The initial water compositions are connected by a line of slope 8 , evaporation enriches both $\square^{2} \mathrm{H}$ and $\square^{18} \mathrm{O}$ along a line of slope 5 . These data suggest that the 
samples represent a strongly evaporated mixture of wastewater and local precipitation. However, the uncertainties preclude an accurate determination of the mixing ratio of the two water sources.

Table 3. HCNO isotopic data for LPGC groundwater samples.

\begin{tabular}{|c|c|c|c|c|c|c|c|c|c|}
\hline State Well ID & $\begin{array}{c}\text { Collection } \\
\text { date }\end{array}$ & $\square^{18} \mathbf{O}_{\text {smow }}$ & $\mathbf{D}_{\text {smow }}$ & ${ }^{3} \mathrm{H}$ & $\square^{13} \mathrm{C}_{\mathrm{PDB}}$ & DIC & ${ }^{14} \mathrm{C}$ & $\begin{array}{c}\square^{15} \mathrm{~N} \\
\text { in Nitrate }\end{array}$ & $\begin{array}{c}\square^{8} \mathrm{O} \\
\text { in Nitrate }\end{array}$ \\
\hline & & (\%o) & (\%o) & $(p C i / L)$ & $(\%)$ & $(\mathrm{mg} / \mathrm{L})$ & (pmc) & (\%o) & (\%o) \\
\hline 03S/01E-01P02 M & 19-Jun-03 & -7.0 & -53 & 42 & & & & 23.6 & 15.9 \\
\hline 03S/01E-01P02 M & 26-Aug-03 & -6.9 & -52 & 49 & & & & 23.6 & 14.7 \\
\hline 03S/01E-01P02 M & 18-Mar-04 & -6.9 & & 41 & -15.9 & 424 & 96.1 & & \\
\hline 03S/01E-01P02 M & 23-Jun-04 & -7.0 & & & & & & & \\
\hline 03S/01E-02J02 M & 26-Aug-03 & -7.1 & -50 & 141 & & & & 29.2 & 11.6 \\
\hline 03S/01E-02J02 M & 18-Mar-04 & -7.1 & & 110 & -18.1 & 675 & 101.6 & & \\
\hline 03S/01E-02Q01 M & 26-Aug-03 & -7.3 & -52 & 139 & & & & 17.4 & 11.8 \\
\hline 03S/01E-02Q01 M & 18-Mar-04 & -7.2 & & 130 & -17.3 & 489 & 104.5 & & \\
\hline 03S/01E-02R01 M & 26-Aug-03 & -7.3 & -53 & 41 & & & & 13.0 & 6.7 \\
\hline 03S/01E-02R01 M & 18-Mar-04 & -7.1 & & 36 & -17.0 & 570 & 96.2 & & \\
\hline 03S/01E-11C03 M & 18-Mar-04 & -7.1 & & 97 & -17.8 & 637 & 98.8 & & \\
\hline
\end{tabular}

DIC - dissolved inorganic carbon pmc - percent modern carbon

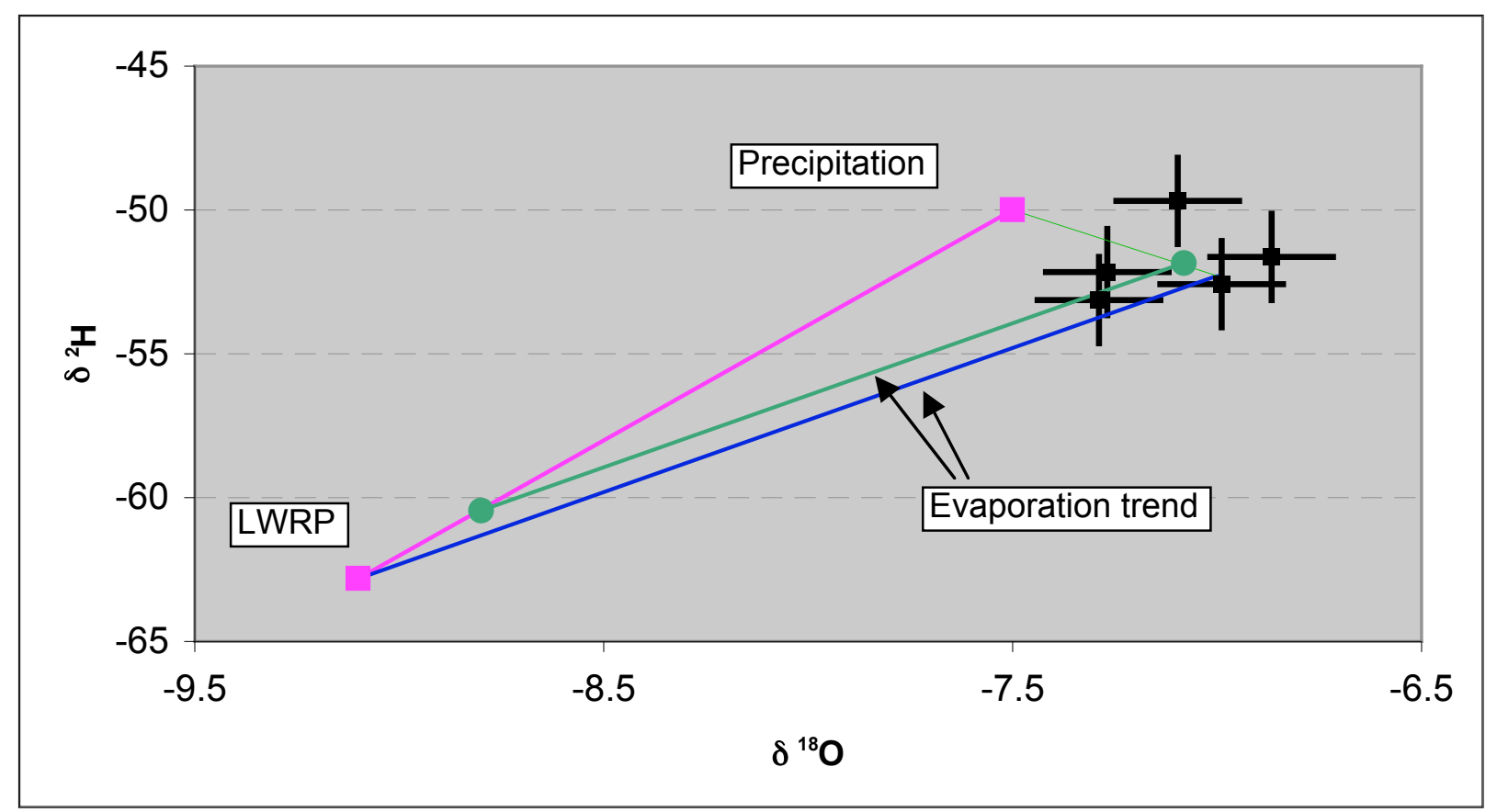

Figure 5. Isotopic signatures for LWRP effluent and LPGC groundwater samples. 
The isotopic composition of $\mathrm{N}$ and $\mathrm{O}$ in the nitrate present in the groundwater samples also shows the contribution of a wastewater component. Denitrification occurring during treatment leads to the correlated enrichment of $\square^{15} \mathrm{~N}$ and $\square^{18} \mathrm{O}$ in the remaining nitrate. All of the groundwater samples show this effect.

\section{${ }^{3} \mathrm{H}-{ }^{3} \mathrm{He}$ AGE DATING OF GROUNDWATER}

The decay of tritium into ${ }^{3} \mathrm{He}$ can be used as a groundwater chronometer. Once water enters the saturated zone (no gas phase present), ${ }^{3} \mathrm{He}$ begins to accumulate in the groundwater and the accumulation age can be calculated using:

$$
\text { Age }(\mathrm{yrs})=17.8 \times \ln \left({ }^{3} \mathrm{He}^{*} /{ }^{3} \mathrm{H}+1\right)
$$

where ${ }^{3} \mathrm{He}^{*}$ is the ${ }^{3} \mathrm{He}$ due to ${ }^{3} \mathrm{H}$ decay:

$$
{ }^{3} \mathrm{He} *={ }^{4} \mathrm{He} \times\left(\left({ }^{3} \mathrm{He} /{ }^{4} \mathrm{He}\right)_{\text {meas }}-0.985 \times\left({ }^{3} \mathrm{He} /{ }^{4} \mathrm{He}\right)_{\text {air }}\right) .
$$

The factor of 0.985 reflects the slightly lower solubility of ${ }^{3} \mathrm{He}$ relative to ${ }^{4} \mathrm{He}$ in water. In addition to the ${ }^{3} \mathrm{H}-{ }^{3} \mathrm{He}$ age, we can compute the concentration of ${ }^{3} \mathrm{H}$ when the groundwater system began to accumulate ${ }^{3} \mathrm{He}$ by adding ${ }^{3} \mathrm{H}^{*}$ to the measured ${ }^{3} \mathrm{H}$ observed in the sample. These data are summarized in Table 4.

\begin{tabular}{|c|c|c|c|c|c|c|c|c|c|c|}
\hline State Well ID & $\begin{array}{c}\text { Collection } \\
\text { date }\end{array}$ & ${ }^{3} \mathrm{He} /{ }^{4} \mathrm{He}$ & ${ }^{4} \mathrm{He}$ & $\mathrm{Ne}$ & $\mathrm{Ar}$ & $\mathbf{K r}$ & $\mathrm{Xe}$ & $\begin{array}{c}{ }^{3} \mathrm{He} \text { from }{ }^{3} \mathrm{H} \\
\text { decay }\end{array}$ & ${ }^{3} \mathrm{H}-{ }^{3} \mathrm{He}$ Age & Initial ${ }^{3} \mathrm{H}$ \\
\hline & & & $\left(\mathrm{cm}^{3} \mathrm{STP} / \mathrm{g}\right)$ & $\left(\mathrm{cm}^{3} \mathrm{STP} / \mathrm{g}\right)$ & $\left(\mathrm{cm}^{3} \mathrm{STP} / \mathrm{g}\right)$ & $\left(\mathrm{cm}^{3} \mathrm{STP} / \mathrm{g}\right)$ & $\left(\mathrm{cm}^{3} \mathrm{STP} / \mathrm{g}\right)$ & $\left(\mathrm{cm}^{3} \mathrm{STP} / \mathrm{g}\right)$ & $(y r)$ & $(p C i / L)$ \\
\hline 03S/01E-01P02 M & 19-Jun-03 & $1.59 \mathrm{E}-06$ & $5.99 \mathrm{E}-08$ & $2.53 \mathrm{E}-07$ & $3.90 \mathrm{E}-04$ & 8.66E-08 & $1.17 \mathrm{E}-08$ & 1.36E-14 & 6.3 & 59 \\
\hline 03S/01E-01P02 M & 26-Aug-03 & 1.61E-06 & 5.92E-08 & 2.53E-07 & 3.89E-04 & 8.57E-08 & 1.16E-08 & 1.47E-14 & 5.8 & 68 \\
\hline 03S/01E-01P02 M & 18-Mar-04 & $1.65 \mathrm{E}-06$ & $5.85 \mathrm{E}-08$ & 2.67E-07 & $3.20 \mathrm{E}-04$ & 8.88E-08 & 1.19E-08 & 1.67E-14 & 7.4 & 63 \\
\hline 03S/01E-01P02 M & 23-Jun-04 & & & & & & & & & \\
\hline 03S/01E-02J02 M & 26-Aug-03 & 4.16E-06 & 7.53E-08 & $3.02 \mathrm{E}-07$ & 4.21E-04 & $9.10 \mathrm{E}-08$ & $1.23 \mathrm{E}-08$ & $2.11 \mathrm{E}-13$ & 19.1 & 412 \\
\hline 03S/01E-02J02 M & 18-Mar-04 & $3.88 \mathrm{E}-06$ & 7.13E-08 & 3.17E-07 & 4.28E-04 & $9.18 \mathrm{E}-08$ & $1.26 \mathrm{E}-08$ & $1.79 \mathrm{E}-13$ & 20.1 & 341 \\
\hline 03S/01E-02Q01 M & 26-Aug-03 & $6.48 \mathrm{E}-06$ & 6.19E-08 & $2.60 \mathrm{E}-07$ & 4.02E-04 & 8.74E-08 & $1.23 \mathrm{E}-08$ & 3.17E-13 & 24.3 & 547 \\
\hline 03S/01E-02Q01 M & 18-Mar-04 & $6.45 \mathrm{E}-06$ & 5.64E-08 & $2.58 \mathrm{E}-07$ & 3.96E-04 & 8.89E-08 & $1.24 \mathrm{E}-08$ & $2.87 \mathrm{E}-13$ & 24.0 & 499 \\
\hline 03S/01E-02R01 M & 26-Aug-03 & 1.70E-06 & 5.91E-08 & 2.46E-07 & 3.97E-04 & 8.62E-08 & $1.22 \mathrm{E}-08$ & 1.97E-14 & 8.5 & 67 \\
\hline 03S/01E-02R01 M & 18-Mar-04 & $1.56 \mathrm{E}-06$ & $5.86 \mathrm{E}-08$ & $2.75 \mathrm{E}-07$ & 3.91E-04 & $8.72 \mathrm{E}-08$ & $1.29 \mathrm{E}-08$ & 1.17E-14 & 6.3 & 51 \\
\hline 03S/01E-11C03 M & 18-Mar-04 & $3.13 \mathrm{E}-06$ & 4.94E-08 & 2.23E-07 & 3.54E-04 & 8.24E-08 & 1.17E-08 & 8.73E-14 & 13.7 & 210 \\
\hline
\end{tabular}

Table 4. Noble gases and ${ }^{3} \mathrm{H}-{ }^{3} \mathrm{He}$ ages. 


\section{HYDROLOGIC MODEL FOR LPGC}

We can look at the relationship between the inferred initial ${ }^{3} \mathrm{H}$ concentration in the groundwater samples as compared to the irrigation water from the LWRP as a function of groundwater age. The ${ }^{3} \mathrm{H}-{ }^{3} \mathrm{He}$ age is close to the water infiltration age but we need to add time for the passage of the water through the unsaturated zone. For a simple piston model, we estimate a 3.5 years travel time. One additional factor comes from the fact that not all of the water in a given sample has the same infiltration history and thus a distribution of ages exists. If the ${ }^{3} \mathrm{H}$ concentration were uniform in time, the ${ }^{3} \mathrm{H}-{ }^{3} \mathrm{He}$ age would equal the mean groundwater age. Since ${ }^{3} \mathrm{H}$ is decreasing with time, the ${ }^{3} \mathrm{H}-{ }^{3} \mathrm{He}$ age is slightly greater than the mean water age and we estimate that, for these samples, the ${ }^{3} \mathrm{H}-{ }^{3} \mathrm{He}$ age is approximately $20 \%$ greater than the mean age of the groundwater. While both of these corrections have significant uncertainty, they are small and of opposite direction and the net impact on the ages is small. These results are summarized in Table 5. We can now compare the inferred ${ }^{3} \mathrm{H}$ concentrations to that present in the irrigation water (Figure 6). We see that the ${ }^{3} \mathrm{H}$ concentrations fall between the two sources and we can calculate that fraction of the groundwater due to the LWRP contribution. We calculate that the LWRP contribution ranges from 27 to $67 \%$ (Figure 7). Our initial estimate of 36 " of irrigation water versus 15 " of precipitation is easily reconciled with this result when we take evaporation into account. Irrigation water applied in the summer undergoes much greater evaporation than does winter precipitation. This model predicts significant enrichment in nonvolatile dissolved components such as chloride. The LWRP wastewater averages $161 \mathrm{mg} / \mathrm{L}$ of $\mathrm{Cl}^{-}$over the period of interest $(1975-2000)$. This is a significant environmental source of $\mathrm{Cl}^{-}$ that dominates other potential sources for these samples. The recovered groundwater samples show values greater than or equal to the LWRP value for $\mathrm{Cl}^{-}$(Figure 8). Thus, we see that even though precipitation accounts for about half of the water, evaporation of the LWRP source more than makes up for this dilution.

Table 5. Summary of water dilution/enrichment analysis.

\begin{tabular}{|c|c|c|c|c|c|c|c|c|c|c|}
\hline State Well ID & $\begin{array}{c}\text { Collection } \\
\text { date }\end{array}$ & ${ }^{3} \mathrm{H}-{ }^{3} \mathrm{He}$ Age & Correction ${ }^{1}$ & $\begin{array}{c}\text { Infiltration } \\
\text { date }\end{array}$ & Initial ${ }^{3} \mathrm{H}$ & LWRP & Precip & $\begin{array}{l}\text { fraction } \\
\end{array}$ & $\mathrm{Cl}$ & $\begin{array}{r}\mathrm{Cl}: \\
\text { GW/LWRP } \\
\end{array}$ \\
\hline & & $(y r)$ & $(y r)$ & & $(p C i / L)$ & $(p C i / L)$ & $(p C i / L)$ & & $(\mathrm{mg} / \mathrm{L})$ & \\
\hline 03S/01E-01P02 M & 19-Jun-03 & 6.3 & 2.2 & 15-Dec-94 & 59 & 108 & 12 & $50 \%$ & 218 & $135 \%$ \\
\hline 03S/01E-01P02 M & 26-Aug-03 & 5.8 & 2.3 & 22-Jun-95 & 68 & 97 & 11 & $66 \%$ & 220 & $137 \%$ \\
\hline 03S/01E-01P02 M & 18-Mar-04 & 7.4 & 2.0 & 4-Oct-94 & 63 & 112 & 12 & $51 \%$ & 166 & $103 \%$ \\
\hline 03S/01E-01P02 M & 23-Jun-04 & & & & & & & & 217 & $135 \%$ \\
\hline 03S/01E-02J02 M & 26-Aug-03 & 19.1 & -0.3 & 19-Nov-84 & 412 & 794 & 44 & $49 \%$ & 694 & $431 \%$ \\
\hline 03S/01E-02J02 M & 18-Mar-04 & 20.1 & -0.5 & 26-Aug-84 & 341 & 832 & 45 & $38 \%$ & 455 & $283 \%$ \\
\hline 03S/01E-02Q01 M & 26-Aug-03 & 24.3 & -1.4 & 6-Sep-80 & 547 & 1829 & 76 & $27 \%$ & 390 & $242 \%$ \\
\hline 03S/01E-02Q01 M & 18-Mar-04 & 24.0 & -1.3 & 3-Jul-81 & 499 & 1554 & 68 & $29 \%$ & 301 & $187 \%$ \\
\hline 03S/01E-02R01 M & 26-Aug-03 & 8.5 & 1.8 & 7-May-93 & 67 & 148 & 14 & $39 \%$ & 186 & $115 \%$ \\
\hline 03S/01E-02R01 M & 18-Mar-04 & 6.3 & 2.2 & 2-Sep-95 & 51 & 93 & 10 & $48 \%$ & 117 & $73 \%$ \\
\hline 03S/01E-11C03 M & 18-Mar-04 & 13.7 & 0.8 & 10-Oct-89 & 210 & 301 & 23 & $67 \%$ & 186 & $115 \%$ \\
\hline
\end{tabular}

1 - Two adjustments are made to the $3 \mathrm{H}-3 \mathrm{He}$ age to convert it to the initial infiltration age. First 3.5 yrs is added to account for travel time in the unsaturated zone. Second a $20 \%$ age reduction is applied as an estimated correction between the mean tritium age and the mean water mass age

2 - Mass fraction of water in the sample from the LWRP, remainder from precipitation 


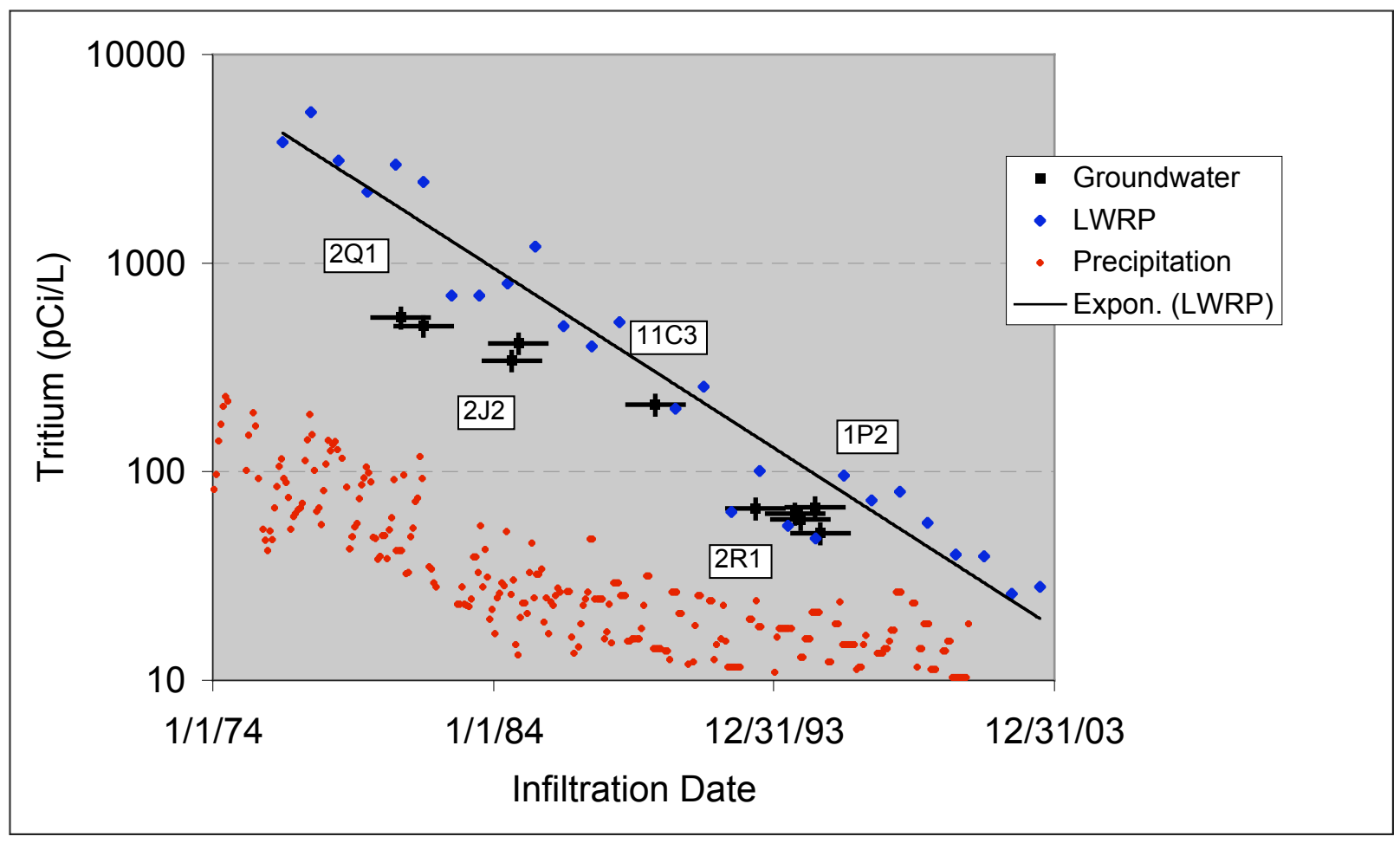

Figure 6. Tritium versus infiltration age.

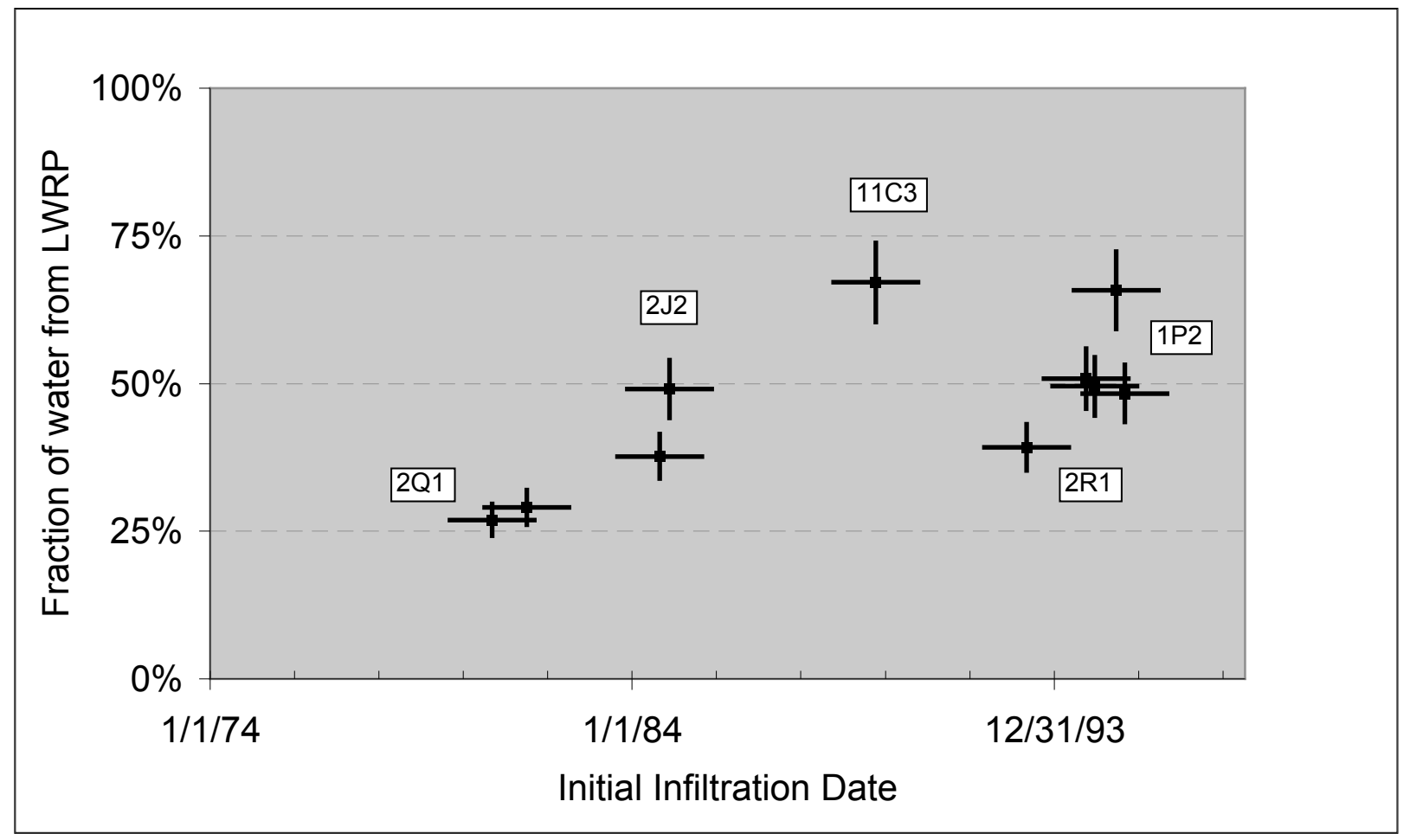

Figure 7. Fraction of groundwater from LWRP versus infiltration age. 


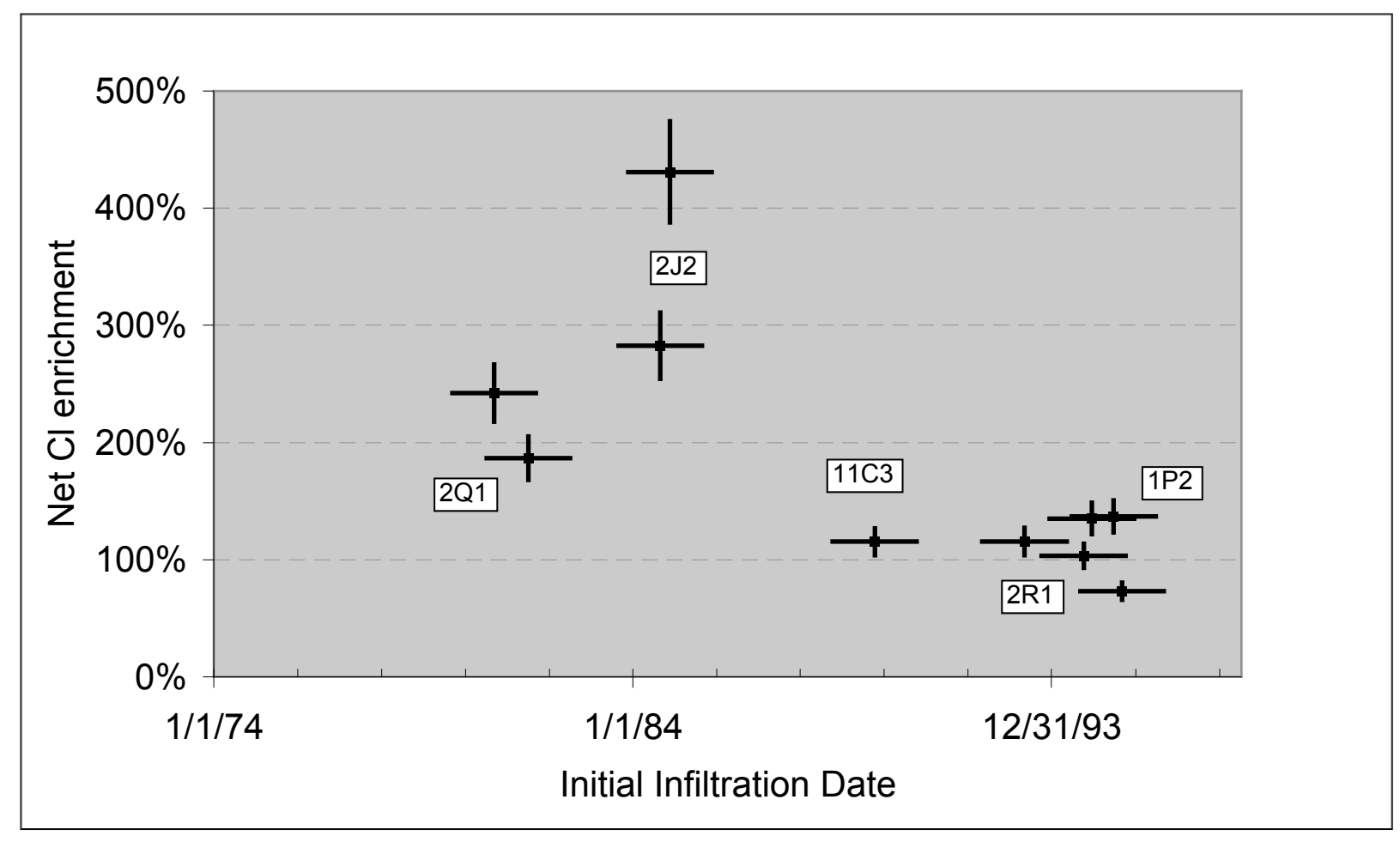

Figure 8. Net chloride enrichment versus infiltration age.

In summary, the recovered groundwater samples for this study were derived from a mixture of wastewater and local precipitation that infiltrated from surface application between about 1980 and 1995. While local precipitation causes some dilution of the wastewater, evaporative enrichment has produced net enrichments of nonvolatile dissolved components such as $\mathrm{Cl}^{-}$. 


\section{EDC TRANSPORT MODEL}

Many EDCs, like NP, have moderate to high organic partitioning coefficients $\left(\mathrm{K}_{\mathrm{oc}}\right)$, so the mass that does not remain soluble often ends up in organic complexes in, or sorbed to, sediments or suspended organic material (Table 6). Additional chemical properties of these APEO metabolites reveal that they have low solubility, moderate estrogen equivalency factors, and relatively high critical micelle formation concentrations (except for the long chained ethoxylates). If mobilized, the EDC complexes may move back into the water column or downward toward groundwater. As part the initial feasibility study, first-order modeling and soil column studies were performed to assess the potential for transport of NP through the vadose zone to the groundwater table.

Table 6. Properties of selected estrogenic EDCs from the literature

\begin{tabular}{|l|c|c|c|c|c|}
\hline EDC & $\begin{array}{c}\text { LogK }_{\text {oc }} \\
(\mathrm{L} / \mathrm{Kg})\end{array}$ & $\begin{array}{c}\text { Solubility } \\
(\mathrm{mg} / \mathrm{L})\end{array}$ & EEF $^{1 .}$ & $\begin{array}{c}\mathbf{C M C}^{2 .} \\
(\mathrm{mg} / \mathrm{L})\end{array}$ & $\mathbf{p K}_{\mathbf{a}}$ \\
\hline 17प-Estradiol (E2) & $3.10-4.01$ & 13.0 & 1.0 & $\mathrm{NA}^{3 .}$ & 10.71 \\
\hline Nonylphenol (NP) & $3.56-5.67$ & $4.9-7.0$ & $7.2 \times 10^{-7}-1.9 \times 10^{-2}$ & $5-13$ & 10.28 \\
\hline $\begin{array}{l}\text { Nonylphenol } \\
\text { ethoxylates } \\
\text { (NP1EO-NPnEO) }\end{array}$ & $3.91-5.64$ & $3.02-7.65$ & $2.0 \times 10^{-7}-1.3 \times 10^{-5}$ & $4.25 \times 10^{-5}$ & $\mathrm{NA}$ \\
\hline Octylphenol & $3.54-5.18$ & 12.6 & $1.0 \times 10^{-5}-4.9 \times 10^{-4}$ & $\begin{array}{c}150 \\
\text { (Trito X-100) }\end{array}$ & NA \\
\hline
\end{tabular}

1. Estrogen Equivalent Factor effect relative to 17-Estradiol - Ranges include various difference bioassays and estrogen receptors including ER-CALUX, YES, E-Screen transgenic zebrafish, and sheepshead minnows, as well as, both $\mathrm{hEH}-\mathrm{\square}$ and $\mathrm{hEH}-\square$ receptors.

2. Critical Micelle Concentration

3. Not available or not found in the literature

[Source: Campbell et al. Submitted, Table 5]

The Burn Model was selected as an empirical transport model that can account for preferential flow (Burns, 1975). In the late 1970s an empirical single-parameter equation was proposed to represent the flow of water and solutes through soils. The Burns Equation was developed primarily to predict one-dimensional nitrate transport in agricultural soils. The original equation was:

$$
X=[I / I+\square \square z]^{z / \square z}
$$

where $\mathrm{X}$ is the fraction of solute leached beyond depth $\mathrm{z}$, I is the cumulative infiltration, and $\square$ is assumed to be the water content at field capacity. The equation, which was developed for uniform soils, was initially formulated to look at both the transport of applied solutes and also the leaching of a resident solute beyond a given soil depth. Although the equation showed promise in heterogeneous soils like shrinking and swelling soils, it was not used often by researchers other than those connected to Burns himself. This is likely due to a few potential theoretical problems resulting in assumptions in the deterministic equation that are physically impossible (Scotter et al., 1993).

However, Scotter et al. (1993) pointed out that the Burns equation could be used as a stochastic representation of solute transport using the transfer function approach (Jury et al., 1982). In this case the physical interpretations of the model are irrelevant as long as the equation 
represents the distribution of solute travel times through isolated stream tubes in the soil. As a transfer function, the model has the special advantage of needing only a single parameter, $\square$, compared to the convection-dispersion equation or the convective lognormal transfer function (Jury and Roth, 1990), which each require at least two parameters.

As a transfer function the Burns equation is used to predict the transport of a solute as:

$$
P(z, I)=\exp \left(\square \frac{z \square}{I}\right)
$$

or the probability that a solute molecule applied to the surface will appear at depth $\mathrm{z}$ after total drainage I. Thus the appropriate form of the equation for a front application or a resident concentration cumulative BTC is:

$$
C_{(z, I)}^{r}=C_{0}^{r}\left[1 \square \exp \left(\square \frac{z \square}{I}\right)\right]
$$

where $\mathrm{C}_{\mathrm{o}}^{\mathrm{r}}$ is the peak resident concentration.

The applicable forms for flux and resident concentration pulses have also been derived by Scotter et al. (1993). For a resident solute pulse, the Burns Equation is:

$$
C_{(z, I)}^{r}=\frac{M \square}{I} \cdot \exp \left(\square \frac{z \square}{I}\right)
$$

and for flux concentrations from resident pulse:

$$
C_{(z, I)}^{f}=\frac{M z \square}{I^{2}} \cdot \exp \left(\square \frac{z \square}{I}\right)
$$

where $\mathrm{M}$ is the total mass per unit area and volume respectively. Solute retardation $(\mathrm{R})$ may be included in the flux concentration equation (White et al., 1998) as follows:

$$
C_{(z, I)}^{f}=\frac{\square M R z \square}{I} \square \cdot \exp \square \frac{R z \square}{I} \square .
$$

A simple linear form of solute retardation may be used:

$$
\mathrm{R}=1+\square_{\mathrm{b}} \mathrm{K}_{\mathrm{d} /} \square
$$

where $\square_{b}$ is the soil bulk density and $K_{d}$ the partitioning coefficient between solution and surface complexation of a contaminant (White et al., 1998). Or for contaminants with a high affinity for organic material a partitioning coefficient for organic carbon may be used:

$$
\mathrm{R}=1+\square \mathrm{b} \mathrm{K}_{\mathrm{oc}} f_{\mathrm{oc}} / \square
$$

The resulting one-dimensional Burns Model for NP transport, given a $\log \mathrm{K}_{\mathrm{oc}}$ value of 3.97, suggests that the chemical would not reach 3 meters $(9.8 \mathrm{ft})$ in 10 years of rain and irrigation, whereas breakthrough of a conservative tracer occurs within the first year (Figure 9). Soil column studies preformed using soils collected for the golf course agreed with the Burns Model with no measurable concentration of NP measurement above the limits of detection. 


\section{Burns Model for Tracer}

Concentration at that depth $(\mathrm{pCi} / \mathrm{L})$

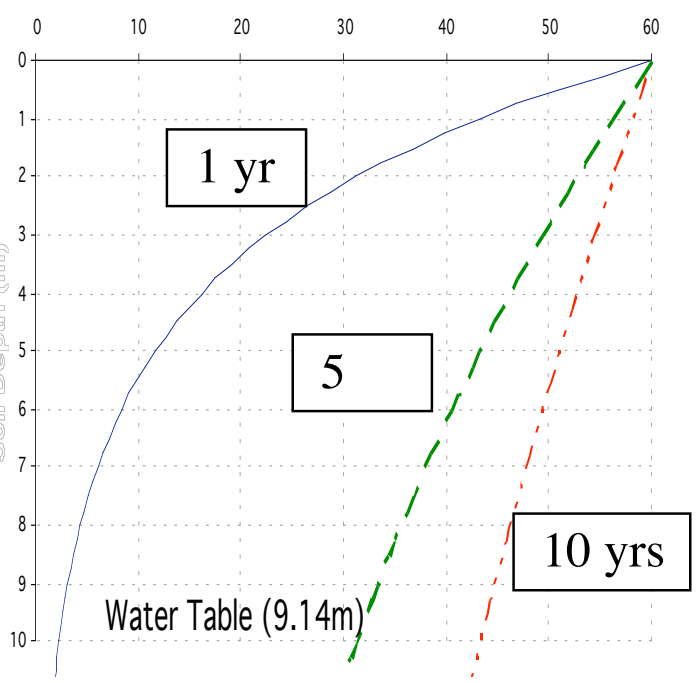

Burns Model for 4-NP

Concentration at that depth (ug/L)

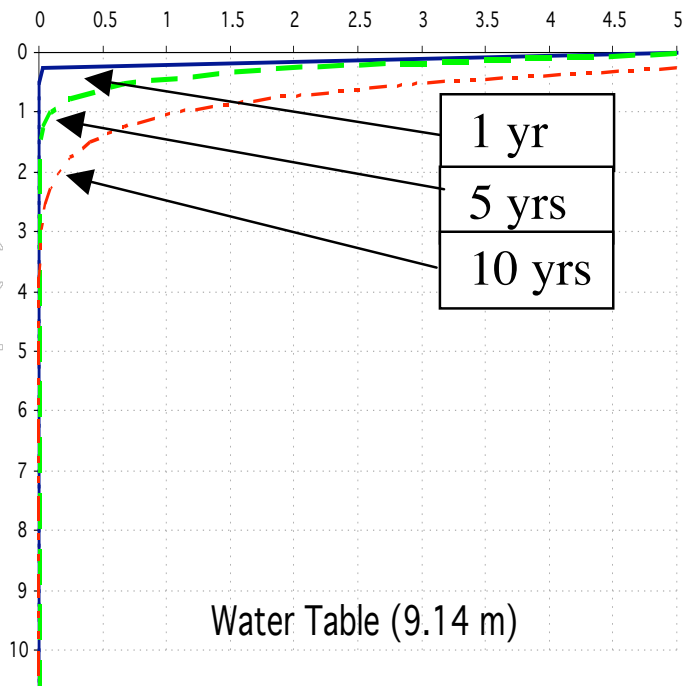

Figure 9. Simulation results using the Burns Model to predict the depth distribution of a conservative tracer (representing water) and NP in the soils under the golf course for 1,5, and 10 years assuming a constant source concentration. Ordinate represents depth in meters.

\section{FIELD SAMPLING PROCEDURES}

Groundwater samples were collected from the Las Positas Golf Course, Livermore, California in July 2002, June 2003, August 2003, March 2004, and June 2004. Monitoring wells are 2" diameter PVC with a 5 or 10' screened interval (Table 1). Depth to water is approximately 20'. Each well was purged three casing volumes prior to sample collection; $\mathrm{pH}$, dissolved oxygen, oxidation reduction potential, conductivity, temperature, and turbidity were measured at each well, and all parameters were stable prior to sample collection. Samples were collected in copper tubes and one-liter pre-cleaned amber IsoChem bottles. Copper tubes were stored at room temperature prior to analysis. Glass bottles were filled directly from the sampling port after triple rinsing each bottle. Bottles were filled to the bottom of the threads for the cap. The samples were stored without preservation at $4{ }^{\circ} \mathrm{C}$ prior to extraction. Gloves were worn by the sampler and care was taken to avoid any contact with other liquids or with skin.

For this study, water samples from the LWRP were collected after tertiary treatment (representative of the water used for irrigation of the LPGC). Specifically, this water had passed through primary treatment (solids removal), secondary treatment (activated sludge, or biological, treatment), and secondary clarifiers (solids removal under quiescent conditions). Tertiary treatment included filtration through "sand beds" with anthracite media, UV disinfection, and chlorination with sodium hypochlorite. 


\section{DEVELOPMENT OF LC/MS/MS METHODS FOR TARGET COMPOUNDS}

A 500-mL sample was spiked with appropriate isotopically-labeled internal standards. For nonylphenol, the internal standard employed for quantification was $\left[\right.$ ring- $\left.{ }^{13} \mathrm{C}_{6}\right]-n$ nonylphenol (Cambridge Isotope Laboratories, Andover, MA). For the other APEO metabolites studied (AP1EC and AP2EC), the internal standard was ${ }^{13} \mathrm{C}_{2}-n$-nonylphenoxyacetic acid (custom-synthesized by Cerilliant, Round Rock, TX); this NP1EC analog was used to represent both AP1EC and AP2EC. For the steroid estrogens 17 - - -estradiol and estrone, the internal standard employed for quantification was 17 -estradiol 16,17,17- $d_{3}$ (ICN, Pointe-Claire, Quebec). Estrone-2,4,16,16- $d_{4}$ 3-sulfate was the internal standard employed for quantification of estrone 3-sulfate (Cambridge Isotope Laboratories, Inc.). For caffeine, the internal standard used for quantification was caffeine-trimethyl ${ }^{13} \mathrm{C}_{3}$ (Sigma Aldrich, MO).

Samples were pre-concentrated employing solid-phase extraction (SPE)(ENVI-18 disks, Supelco, Bellefonte, PA), followed by elution of the analytes with $10 \mathrm{~mL}$ of ultra-pure methanol. This constituted a 50-fold concentration of the analytes. Additionally, for each batch of samples, a 500-mL aliquot of reagent water was spiked with internal standards and extracted simultaneously with the aqueous samples. To improve sensitivity for some target analytes (e.g., 17--estradiol and estrone), an aliquot of the methanol extract was concentrated (e.g., 10-fold from $2 \mathrm{~mL}$ to $200 \mathrm{LL}$ ) with a gentle stream of nitrogen gas prior to LC/MS/MS analysis.

A Waters Model 2690 (Waters Corporation, Milford, MA) HPLC (High Performance Liquid Chromatography) instrument with a Nova-Pak $\mathrm{C}_{18}$ column $(150 \times 2.1 \mathrm{~mm}, 4-\square \mathrm{m}$ particle size; Waters Corporation) was used for chromatographic separation of analytes. The sample injection volume was $25 \square \mathrm{L}$. The mobile phase typically consisted of methanol:reagent water mixtures, with the flow rates ranging from 100-200 $\mathrm{L} / \mathrm{min}$, depending on the analyte of interest. In some cases, chromatographic optimization studies revealed that methanol:water mixtures were not sufficient for good chromatographic separation or retention. For example, chromatographic separation of estrone 3-sulfate was achieved with a 40:60 mixture of methanol and $5 \mathrm{mM}$ ammonium acetate (in 90\% water:10\% methanol) and chromatographic separation of APECs was achieved with a 65:35 mixture of those two eluents.

A triple quadrupole mass spectrometer - Quattro LC ${ }^{\mathrm{TM}}$ (Micromass, Manchester, UK) was employed for mass determination and quantification. Operating conditions included a nitrogen flow rate of $75 \mathrm{~L} / \mathrm{hr}$ for the nebulizer and a flow rate of $350 \mathrm{~L} / \mathrm{hr}$ during desolvation. Ion source temperatures were $80^{\circ} \mathrm{C}$ for the source block and $300^{\circ} \mathrm{C}$ for desolvation. Compoundspecific optimization of MS and MS/MS parameters (e.g., sample cone voltage, capillary voltage, collision energy) for method development involved infusions of standards (typically 10 $\square \mathrm{L} / \mathrm{min}$ for a $200 \square \mathrm{g} / \mathrm{L}$ standard) and acquisition in full-scan mode or daughter ion mode. Optimized parameters are listed in Table 7. Isotope dilution quantification (with compoundspecific corrections for internal standard recovery) was performed in selected reaction monitoring mode for all analytes. Representative calibration curves for target analytes in this study are presented in Figures 10-13. 
Table 7. Trace organic compounds of interest.

\begin{tabular}{|c|c|c|c|c|c|c|}
\hline Compound & $\begin{array}{c}\text { Pre- } \\
\text { concentration } \\
\text { Technique }^{\mathrm{a}}\end{array}$ & $\begin{array}{l}\text { Ionization } \\
\text { Mode }\end{array}$ & Instrumentation & Transitions $(m / z)$ & $\begin{array}{l}\text { Internal Standard } \\
\text { Transitions }(\mathrm{m} / \mathrm{z})^{\mathrm{b}}\end{array}$ & $\begin{array}{c}\text { Detection Limit }^{\mathrm{a}} \\
(\mathrm{ng} / \mathrm{L})\end{array}$ \\
\hline Caffeine & SPE & $\begin{array}{c}\text { Positive } \\
\text { Electrospray }\end{array}$ & $\mathrm{LC} / \mathrm{MS} / \mathrm{MS}^{\mathrm{c}}$ & $m / z 195 \rightarrow m / z, 138$ & $m / z, 198 \rightarrow m / z, 140$ & $5-10$ \\
\hline 4-Nonylphenol & SPE & $\begin{array}{c}\text { Negative } \\
\text { Electrospray }\end{array}$ & LC/MS/MS & $m / z 219 \rightarrow m / z 133$ & $m / z 225 \rightarrow m / z, 112$ & $10-15$ \\
\hline $\mathrm{NP} \mathrm{EC}^{\mathrm{d}}$ & SPE & $\begin{array}{c}\text { Negative } \\
\text { Electrospray }\end{array}$ & $\mathrm{LC} / \mathrm{MS} / \mathrm{MS}$ & $m / z 277 \rightarrow m / z 219$ & $m / z 279 \rightarrow m / z 219$ & 40 \\
\hline $\mathrm{NP} 2 \mathrm{EC}^{\mathrm{e}}$ & SPE & $\begin{array}{c}\text { Negative } \\
\text { Electrospray }\end{array}$ & $\mathrm{LC} / \mathrm{MS} / \mathrm{MS}$ & $m / z 321 \rightarrow m / z 219$ & $m / z 279 \rightarrow m / z 219^{\mathrm{e}}$ & 100 \\
\hline 17ฤ-estradiol & SPE & $\begin{array}{c}\text { Negative } \\
\text { Electrospray }\end{array}$ & $\mathrm{LC} / \mathrm{MS} / \mathrm{MS}$ & $\begin{array}{c}m / z 271 \rightarrow m / z 143, \\
145,183\end{array}$ & $\begin{array}{c}m / z 274 \rightarrow m / z 145, \\
185\end{array}$ & $1-10$ \\
\hline Estrone & SPE & $\begin{array}{c}\text { Negative } \\
\text { Electrospray }\end{array}$ & $\mathrm{LC} / \mathrm{MS} / \mathrm{MS}$ & $\begin{array}{c}m / z 269 \rightarrow m / z 143, \\
145\end{array}$ & $\begin{array}{c}m / z 274 \rightarrow{ }_{185^{\mathrm{f}}}^{m / z} 145, \\
\end{array}$ & $1-10$ \\
\hline Estrone 3-sulfate & SPE & $\begin{array}{c}\text { Negative } \\
\text { Electrospray }\end{array}$ & $\mathrm{LC} / \mathrm{MS} / \mathrm{MS}$ & $m / z 349 \rightarrow m / z, 269$ & $m / z 353 \rightarrow m / z, 273$ & 5 \\
\hline
\end{tabular}

${ }^{a}$ Estimated detection limits are based on solid-phase extraction, SPE, (ENVI-18 disks, Supelco, Bellefonte, PA) of a 0.5-L aqueous sample and accounting for typical extraction blank concentration levels.

${ }^{b}$ Isotopically- $\left({ }^{13} \mathrm{C}\right.$ or $\left.{ }^{2} \mathrm{H}\right)$ labeled internal standards were employed for isotope dilution liquid chromatography/tandem mass spectrometry unless noted otherwise.

${ }^{\mathrm{c}} \mathrm{LC} / \mathrm{MS} / \mathrm{MS}=$ Liquid Chromatography/Tandem Mass Spectrometry.

${ }^{\mathrm{d}}$ Nonylphenoxyacetic acid (Figure 1), a metabolite of alkylphenol ethoxylates.

${ }^{\mathrm{e}}$ Nonylphenoxyethoxyacetic acid (Figure 1), a metabolite of alkylphenol ethoxylates; the internal standard for NP1EC was also used for NP2EC.

${ }^{\mathrm{f}}$ The internal standard for 17ฤ-estradiol was also used for estrone. 


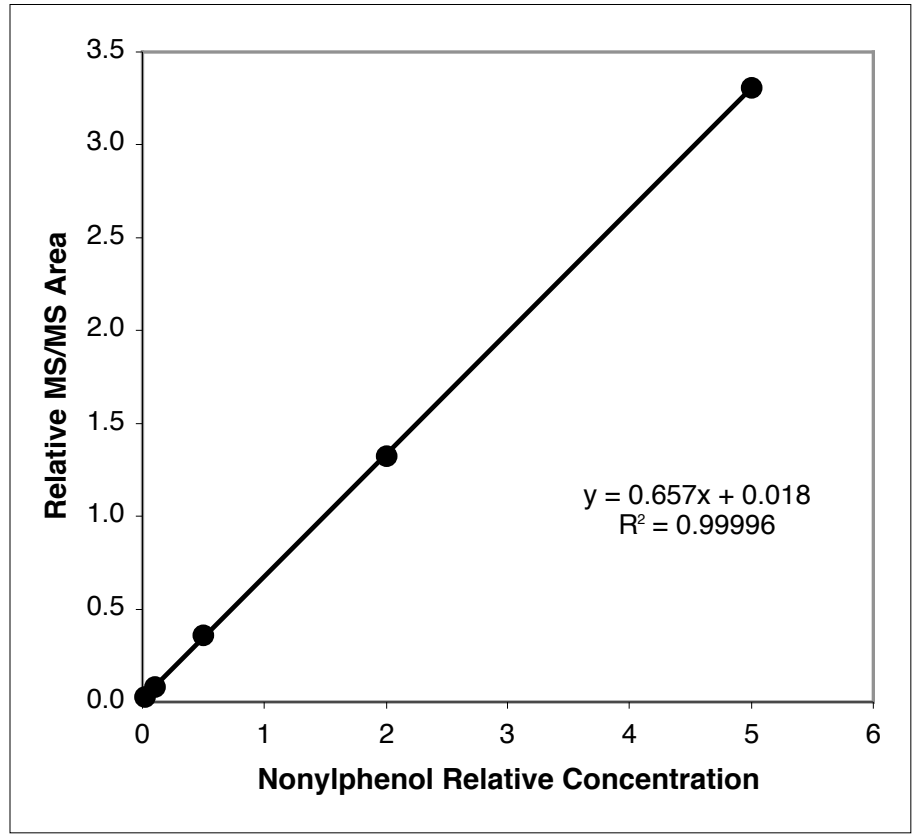

Figure 10. Internal standard calibration for NP. Standard concentrations (accounting for a 0.5-L sample processed through SPE) range from 20 to $5000 \mathrm{ng} / \mathrm{L}$.

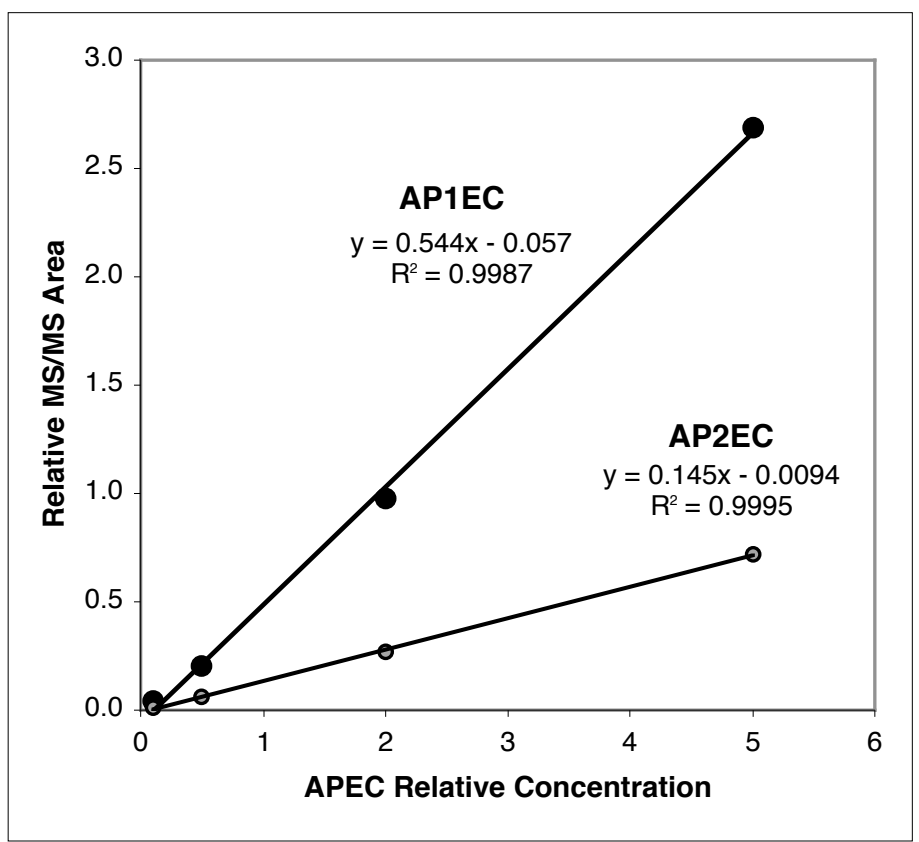

Figure 11. Internal standard calibration for AP1EC and AP2EC. Standard concentrations (accounting for a 0.5-L sample processed through SPE) range from 100 to $2000 \mathrm{ng} / \mathrm{L}$. 


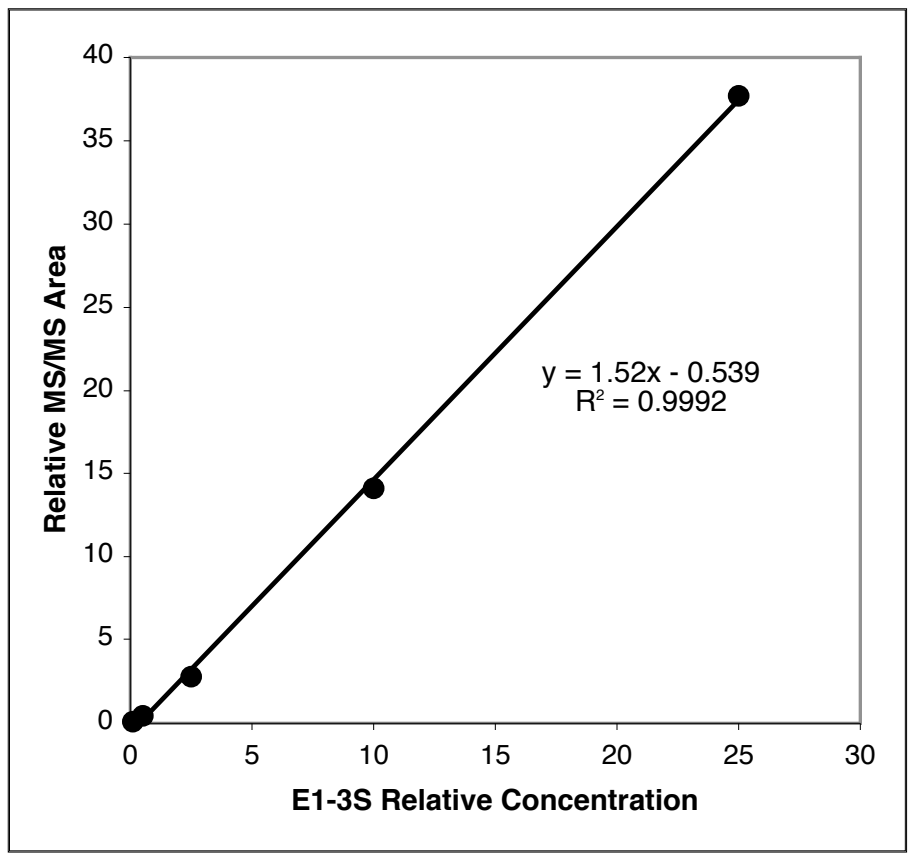

Figure 12. Internal standard calibration for estrone 3-sulfate. Standard concentrations (accounting for a 0.5-L sample processed through SPE) range from 20 to $5000 \mathrm{ng} / \mathrm{L}$.

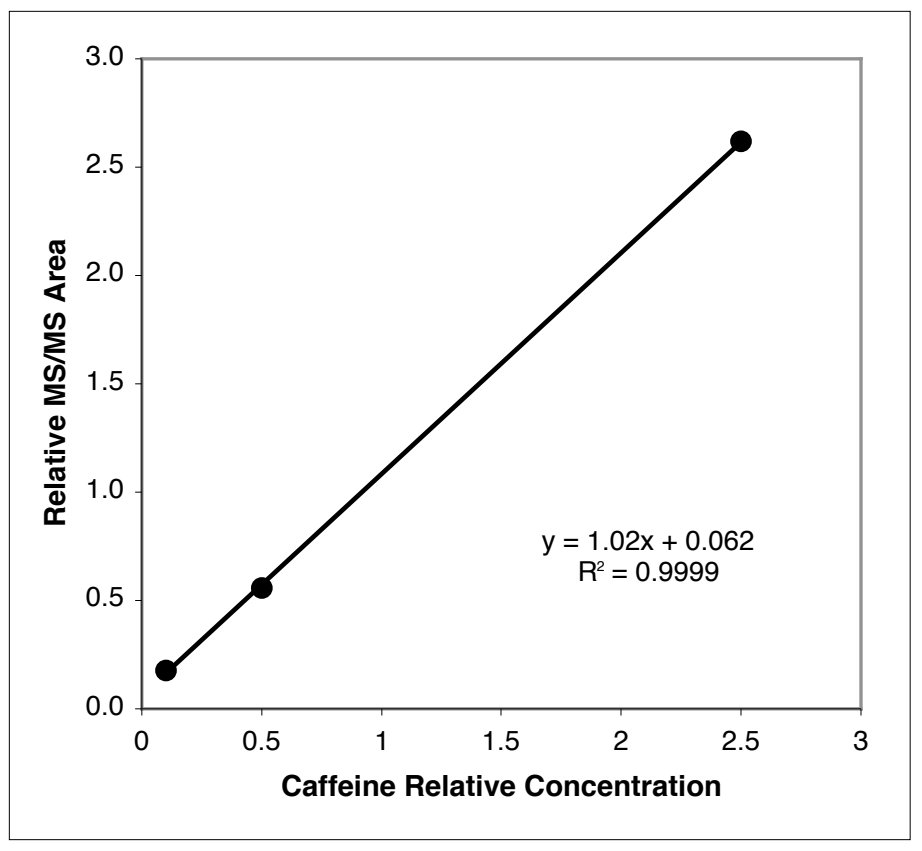

Figure 13. Internal standard calibration for caffeine. Standard concentrations (accounting for a 0.5-L sample processed through SPE) range from 20 to $500 \mathrm{ng} / \mathrm{L}$. 


\section{LC/MS/MS RESULTS}

\section{LWRP EFFLUENT (IRRIGATION WATER) RESULTS}

Concentrations of NP, AP1EC, AP2EC, and caffeine in tertiary-treated effluent samples collected from the LWRP between 2002 and 2004 are given in Table 8. For NP, concentrations averaged $3 \square \mathrm{g} / \mathrm{L}$ and consistently fell between 2 and $4 \square g / L$. These concentrations agree well with data reported for treated effluent from other WWTPs (e.g., Johnson and Sumpter, 2001 and references therein). A typical LC/MS/MS chromatogram of NP in a LWRP effluent sample (Figure 14) illustrates the very high signal:noise ratios observed in these samples. Analytical recovery of the labeled NP internal standard was considerably lower than typically observed with groundwater samples (e.g., Table 9) and method blanks. Thus, it is likely that the lower "recovery" resulted from signal suppression from the complex effluent matrix rather than loss of NP during sample treatment. Concentrations of AP1EC and AP2EC are reported only for the period when internal standard quantification was possible (i.e., after the custom synthesis of the labeled AP1EC internal standard was completed). The overall average concentrations of 18 $\square \mathrm{g} / \mathrm{L}$ for AP1EC and $61 \square \mathrm{g} / \mathrm{L}$ for AP2EC are well within the range of values reported previously for treated WWTP effluents (e.g., Field and Reed, 1996). The APEC results also agree qualitatively with published data from other WWTPs (Field and Reed, 1996) in the sense that AP2EC concentrations were consistently greater than AP1EC concentrations (for this study, by an average factor of 3 to 4 and in other studies by a factor of 3 to 14). Analytical recoveries of the labeled AP1EC internal standard were considerably higher than for NP, which may be explained by the different eluent and higher mass range used for APEC analysis. Caffeine, which is not an EDC but does have value as a wastewater indicator compound, was only measured for this study in July 2003. The concentration, near $0.5 \square \mathrm{g} / \mathrm{L}$, is in the range of values reported for other WWTP effluents (Seiler et al., 1999; Buerge et al., 2003 and references therein).

The following compounds were not observed in LWRP samples:

- Estrone 3-sulfate was not detected in LWRP samples (grab and composite) collected in July 2003 despite detection limits on the order of $0.5 \mathrm{ng} / \mathrm{L}$ (the extract was concentrated 10 -fold more than for other analytes) and satisfactory analytical recovery of the labeled internal standard ( 23 to $72 \%$ recovery).

- Semi-quantitative results indicate that collected LWRP effluent and groundwater samples did not contain 17--estradiol or estrone at detectable concentration levels (i.e., above 5 $\mathrm{ng} / \mathrm{L}$ ). Extraction method blank samples had satisfactory surrogate standard recoveries and did not contain detectable levels of these compounds. Notably, surrogate standard recoveries in LWRP effluent and groundwater samples for the isotopically labeled 17 estradiol standard were low $(<10 \%)$. The total dissolved solids content in LWRP effluent and groundwater samples was relatively high, and may have contributed to the low surrogate recoveries (i.e., electrospray ion suppression). As described previously, to improve sensitivity for 17D-estradiol and estrone in samples, an aliquot of the methanol extract was concentrated (e.g., 10-fold) prior to LC/MS/MS analysis; analysis of 
methanol extracts that had not been concentrated also showed poor surrogate recoveries. Furthermore, standard addition experiments were conducted with the concentrated groundwater extracts, and percent recoveries remained low. 
Table 8. NP, APEC, and caffeine concentrations in the LWRP (Livermore Wastewater Recycling Plant) tertiary effluent.

\begin{tabular}{|c|c|c|c|c|c|c|c|}
\hline Sampling date & $\begin{array}{c}\text { NP } \\
(\square \mathbf{g} / \mathbf{L})\end{array}$ & $\begin{array}{c}\text { NP } \\
\text { recovery }(\%)\end{array}$ & $\begin{array}{c}\text { AP1EC } \\
(\square g / L)\end{array}$ & $\begin{array}{c}\text { AP1EC } \\
\text { recovery }(\%)\end{array}$ & $\begin{array}{c}\text { AP2EC } \\
(\square \mathbf{g} / \mathbf{L})\end{array}$ & $\begin{array}{c}\text { Caffeine } \\
(\square \mathrm{g} / \mathrm{L})\end{array}$ & $\begin{array}{c}\text { Caffeine } \\
\text { recovery }(\%)\end{array}$ \\
\hline Sept. 2002 & 3.5 & 38 & & & & & \\
\hline July 2003(grab) & $3.1 \pm 0.7^{\mathrm{a}}$ & $41 \pm 14$ & & & & $0.51 \pm 0.29$ & $6.9 \pm 2.9$ \\
\hline July 2003(composite) & $2.9 \pm 0.2$ & $15 \pm 2.3$ & & & & $0.54+0.07$ & $6.5 \pm 3.4$ \\
\hline April 2004 & & & $26 \pm 0.7$ & $98 \pm 10$ & $86 \pm 8.0$ & & \\
\hline May 2004 & 2.7 & 55 & 15 & 70 & 65 & & \\
\hline June 2004 & & & $12 \pm 0.7$ & $102 \pm 4.1$ & $32 \pm 1.9$ & & \\
\hline Overall average & 3.0 & & 18 & & 61 & 0.53 & \\
\hline
\end{tabular}

a Mean \pm standard deviation.

Table 9. NP, APEC, and caffeine concentrations in groundwater near the Livermore golf course.

\begin{tabular}{|c|c|c|c|c|c|c|c|}
\hline Sampling date & $\begin{array}{c}\mathbf{N P} \\
(\mathbf{n g} / \mathbf{L}) \\
\end{array}$ & $\begin{array}{c}\mathrm{NP} \\
\text { recovery }(\%) \\
\end{array}$ & $\begin{array}{c}\text { AP1EC } \\
(\mathbf{n g} / \mathrm{L})\end{array}$ & $\begin{array}{c}\text { AP1EC } \\
\text { recovery }(\%)\end{array}$ & $\begin{array}{c}\text { AP2EC } \\
(\mathbf{n g} / \mathbf{L})\end{array}$ & $\begin{array}{c}\text { Caffeine } \\
(\mathrm{ng} / \mathrm{L})\end{array}$ & $\begin{array}{c}\text { Caffeine } \\
\text { recovery }(\%)\end{array}$ \\
\hline July 2002 & 60 to $1800(\mathrm{~A}, \mathrm{~B}, \mathrm{E})^{\mathrm{a}}$ & 32 to 96 & & & & & \\
\hline June 2003 & 1000 to 2000 (A;4 others) & 46 to 73 & & & & & \\
\hline August 2003 & 220 to $820(\mathrm{~A}-\mathrm{D})$ & 38 to 86 & $<40$ to $140(\mathrm{~A}-\mathrm{C})$ & 72 to 90 & $\begin{array}{c}<100 \text { to } 170 \\
(\mathrm{~A}-\mathrm{C})\end{array}$ & & \\
\hline March 2004 & $<11(\mathrm{~A}-\mathrm{D}, \mathrm{F})^{\mathrm{b}}$ & 62 to 90 & $<10$ to $65(\mathrm{~A}-\mathrm{D}, \mathrm{F})$ & 72 to 88 & $<100(\mathrm{~A}-\mathrm{D}, \mathrm{F})$ & $<5(\mathrm{~A}-\mathrm{D})$ & $13-23$ \\
\hline June 2004 & $<$ blank $(\mathrm{A})^{\mathrm{b}, \mathrm{c}}$ & 66 & $<40(\mathrm{~A})$ & 105 & $<150(\mathrm{~A})$ & & \\
\hline
\end{tabular}

a Sampling locations: A=1P2, B=2R1, C=2J2, D=2Q1, E=11B1, F=11C3 (see Figure 2 for well locations).

${ }^{\mathrm{b}}$ Sampling artifacts for NP were effectively minimized by March 2004 (shaded region); all previous NP data are highly unlikely to be representative because of probable sampling artifacts.

${ }^{\mathrm{c}} \mathrm{NP}$ in the method blank run on June 2004 was $360 \mathrm{ng} / \mathrm{L}$. 


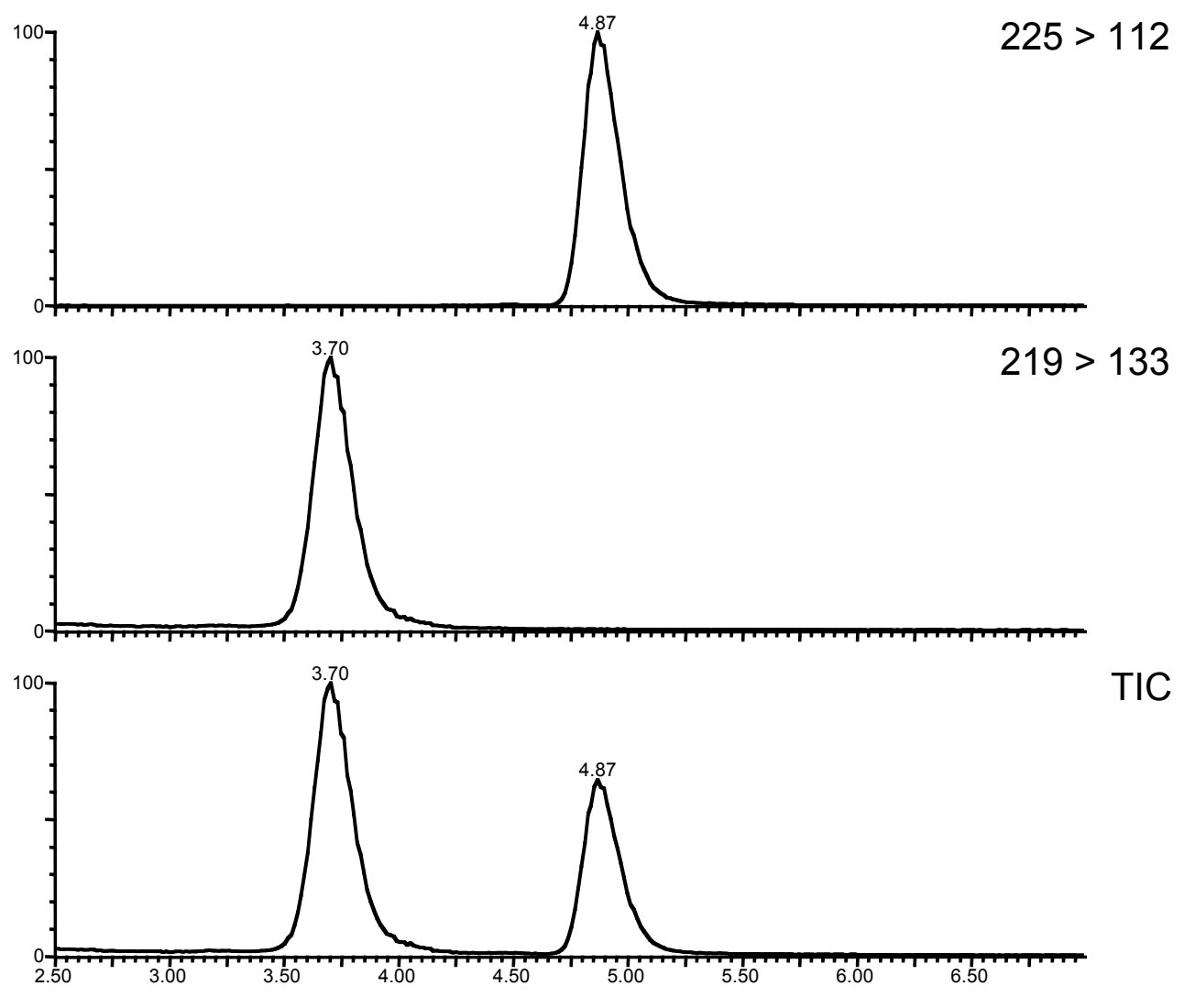

Figure 14. Typical LC/MS/MS chromatogram of NP $(m / z 219 \rightarrow 133)$ in an LWRP effluent sample. The effective concentration of the internal standard $(m / z 225 \rightarrow 112)$ is $1 \square \mathrm{g} / \mathrm{L}$. 


\section{LPGC GROUNDWATER RESULTS}

Concentrations of NP, AP1EC, AP2EC, and caffeine in groundwater samples collected from the LPGC area between 2002 and 2004 are compiled in Table 9. Note that concentrations in Table 9 are given in $\mathrm{ng} / \mathrm{L}$, whereas those in Table 8 are given in $\mathrm{gg} / \mathrm{L}$. For samplings before March 2004, NP concentrations ranged widely (between 60 and $2000 \mathrm{ng} / \mathrm{L}$ ) and surprisingly approached the concentrations observed in the LWRP effluent ( $3000 \mathrm{ng} / \mathrm{L}$; Table 8$)$. It was eventually determined that the downhole pump was a source of NP contamination for groundwater samples; this was even the case when the well was purged with the pump but sampled with a Teflon bailer. In March 2004, when a new groundwater pumping system was implemented that included Teflon tubing, NP was no longer detectable in groundwater samples $(<11 \mathrm{ng} / \mathrm{L}$; Table 9). Notably, analytical recoveries of the NP internal standard were favorable in these samples (62-90\%; Table 9), demonstrating that the lack of NP detection was not due to inefficient extraction. Although NP was detected in a later sampling with the improved sampling equipment (June 2004), concentrations were below the concentration in a method blank processed in parallel with the samples; thus, these detections cannot be considered valid. These results indicate that NP concentrations in groundwater were at least 270-fold lower than those in the irrigation water (i.e., LWRP effluent). AP1EC and AP2EC were occasionally detected in groundwater samples, but at concentrations of less than $200 \mathrm{ng} / \mathrm{L}$. An LC/MS/MS chromatogram of APECs in a groundwater sample (Figure 15) illustrates that these peaks could be easily distinguished from background in this matrix. The maximum detected concentrations of AP1EC and AP2EC in groundwater occurred in wells 2J2 and 2R1 and were 130-fold and 360 -fold lower, respectively, than the average concentrations in irrigation water. Unlike the qualitative trends observed in the LWRP effluent samples, AP2EC concentrations were not consistently higher than AP1EC concentrations in groundwater samples. Caffeine was not detected in groundwater at a detection limit that was $\sim 100$-fold lower than the average concentration in the irrigation water. Estrone 3-sulfate (data not shown) was not detected in three groundwater samples collected in July 2002 despite high analytical recovery (86 to 103\%).

Overall, concentrations of NP, AP1EC, AP2EC, and caffeine were from 130- to 360fold lower in groundwater than in irrigation water (i.e., LWRP effluent). Since hydrological modeling indicates that irrigation water was diluted only 33 to $73 \%$ with local precipitation in the aquifer, attenuation of these compounds during transport through the vadose zone and saturated zone (e.g., by sorption for the APEO metabolites and by biodegradation for caffeine) must have been very substantial. Sorption of NP is not surprising considering its highly hydrophobic nature (e.g., Table 6, Figure 9). 


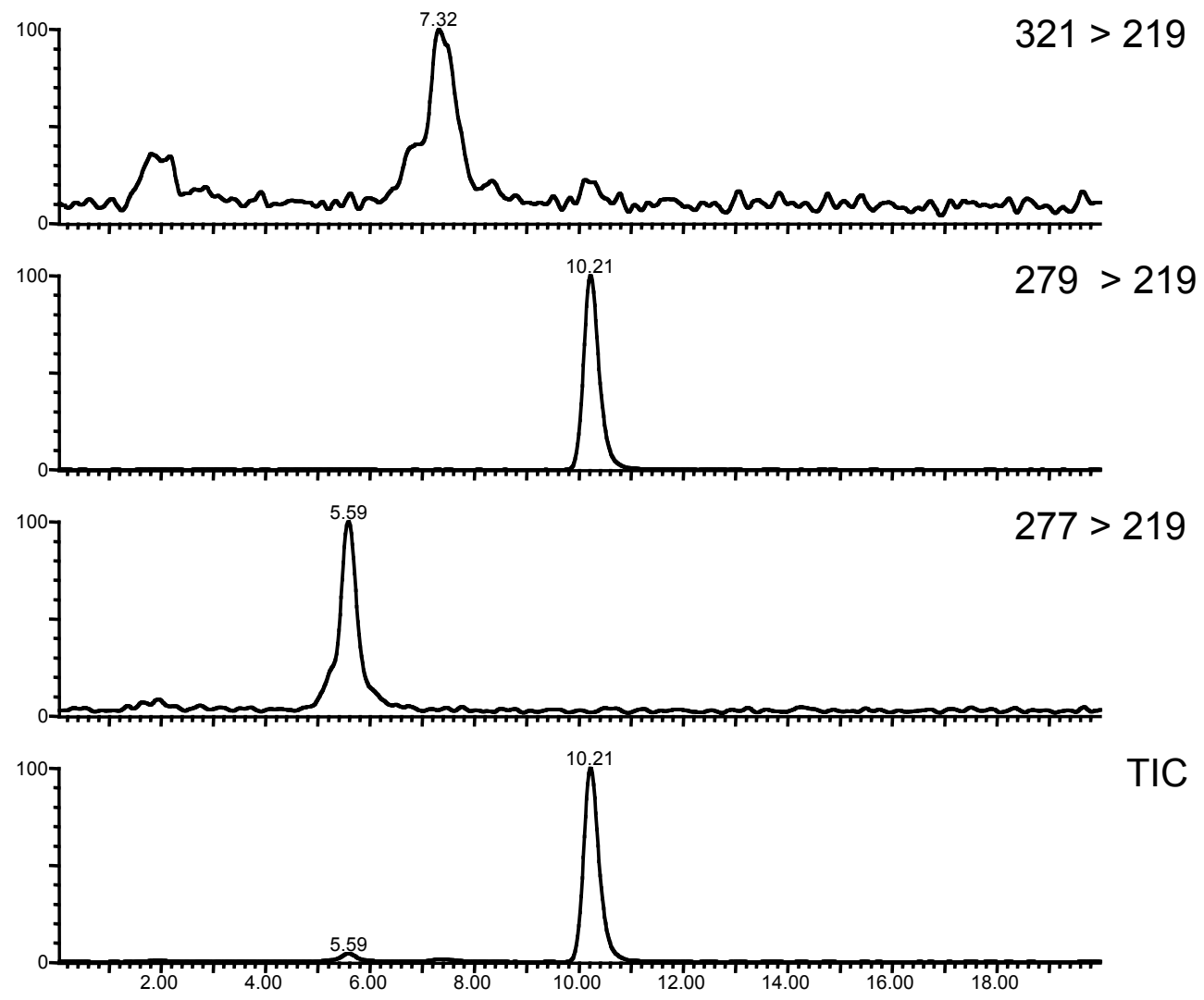

Figure 15. LC/MS/MS chromatogram of AP1EC $(\mathrm{m} / z$ 277 $\rightarrow 219)$ and AP2EC $(\mathrm{m} / z$ 321 $\rightarrow 219)$ in an LPGC groundwater sample. The effective concentration of the internal standard $(\mathrm{m} / \mathrm{z}$ $279 \rightarrow 219)$ is $1 \square g / L$. 


\section{BIOASSAY FOR ESTROGENIC ACTIVITY}

In vitro assays for estrogenic activity provide an integrated measure of estrogenic potency of environmental samples without requiring knowledge of all bioactive compounds in the samples. Chemical analysis of all known estrogenic compounds would be extremely costly and time-consuming. In addition, unknown estrogenic compounds may be present. Several different bioassays have been developed and have been tested for application to wastewater and surface water (Zacharewski, 1997; Murk et al., 2002) including cell proliferation assays (Soto et al., 1995), and reporter gene approaches including yeast-based screens (Routledge et al., 1996) and human cell line screens (Legler et al., 1999). Based on our initial investigation of available bioassays, we focused on a system using a human breast cancer cell line (MCF-7) including a dual-luciferase assay (Promega) for application to the target compounds and groundwater samples. We performed a quantitative assessment of the bioassay including analysis of reproducibility, detection limit, and response range. After bioassay optimization for the environmental matrices, we applied the assay to both LPGC groundwater and LWRP effluent. Estrogenic potencies from the bioassay were subsequently correlated with chemical data obtained as described previously.

The reporter bioassay system employed is based on an estrogen-responsive luciferase reporter system. The human epithelial breast cancer cell line MCF-7 was used as a host. MCF-7 cells contain endogenous estrogen receptors and have been well characterized in terms of their response to estrogenic stimuli. The cells were transfected with a plasmid containing an estrogenresponsive reporter construct with three estrogen-responsive elements (EREs) upstream of the luciferase reporter gene (EREx3-Luc; Figure 16). This plasmid was co-transfected with a commercially available control Renilla reporter plasmid (pRL-TK, Promega) to monitor the transfection efficiency and to normalize the luciferase activity.

MCF7 cells (purchased from the American Type Culture Collection, or ATCC) were maintained in DMEM medium containing 10\% fetal bovine serum (FBS), $2 \mathrm{mM}$ glutamine and 1 $\mathrm{mg} / \mathrm{mL}$ insulin. MCF7 cells were plated in 6-well trays at $2 \times 10^{6}$ cells/well in phenol red-free DMEM medium containing 10\% charcoal-stripped FBS and insulin (CS-DMEM) and incubated at $37^{\circ} \mathrm{C}$ for $24 \mathrm{~h}$. Experimental variability was significantly reduced by transfecting cells in larger batches and subsequently splitting cells after trypsinization. Immediately before transfection, the medium was changed to $2 \mathrm{~mL}$ of phenol red-free Opti-MEM (Invitrogen) with reduced serum. Transfection was performed using Lipofactamine 2000 (Invitrogen) with EREx3luc $(5 \mu \mathrm{g} / \mathrm{well})$ and Renilla control plasmids $(5 \mu \mathrm{g} / \mathrm{well})$ per the manufacturer's instructions. The cells were exposed to the plasmids for $24 \mathrm{~h}$.

The transfected cells were trypsinized and plated in a 96-well tray at $2 \times 10^{4}$ cells/well, and incubated at $37^{\circ} \mathrm{C}$ for $6 \mathrm{~h}$. The cells were treated with 17 -estradiol $\left(\mathrm{E}_{2}\right)$ as a positive control or $\mathrm{NP}$ at various concentrations in ethanol at $2 \mu \mathrm{L}$. The same volume of ethanol was used as a control. For water samples, $5 \mathrm{~mL}$ of CS-DMEM was lyophilized and the water sample was used to reconstitute the medium. LWRP water containing chlorine (residue from disinfection) was pre-treated by purging with $\mathrm{N}_{2}$ for $15 \mathrm{~min}$ or by addition of $20 \square \mathrm{M}$ sodium thiosulfate, which reduces chlorine to chloride ions. Cells were suspended in reconstituted medium and $200 \mu \mathrm{L}$ of 
cells were plated in each well of the 96-well tray. Each treatment had eight replicate wells. The cells were incubated with $\mathrm{E}_{2}$, NP, or ethanol in the reconstituted medium at $37^{\circ} \mathrm{C}$ for $18 \mathrm{~h}$ and luciferase and Renilla activity were determined on a luminometer using a dual luciferase/Renilla reporter assay kit (Promega) according to the manufacturer's instructions. Luciferase activity was normalized to the Renilla controls and expressed as fold induction relative to the untreated (ethanol) control. Luciferase activity in the water samples was compared to 17 -estradiol or NP, which were standards for the estrogen-responsive luciferase assays.

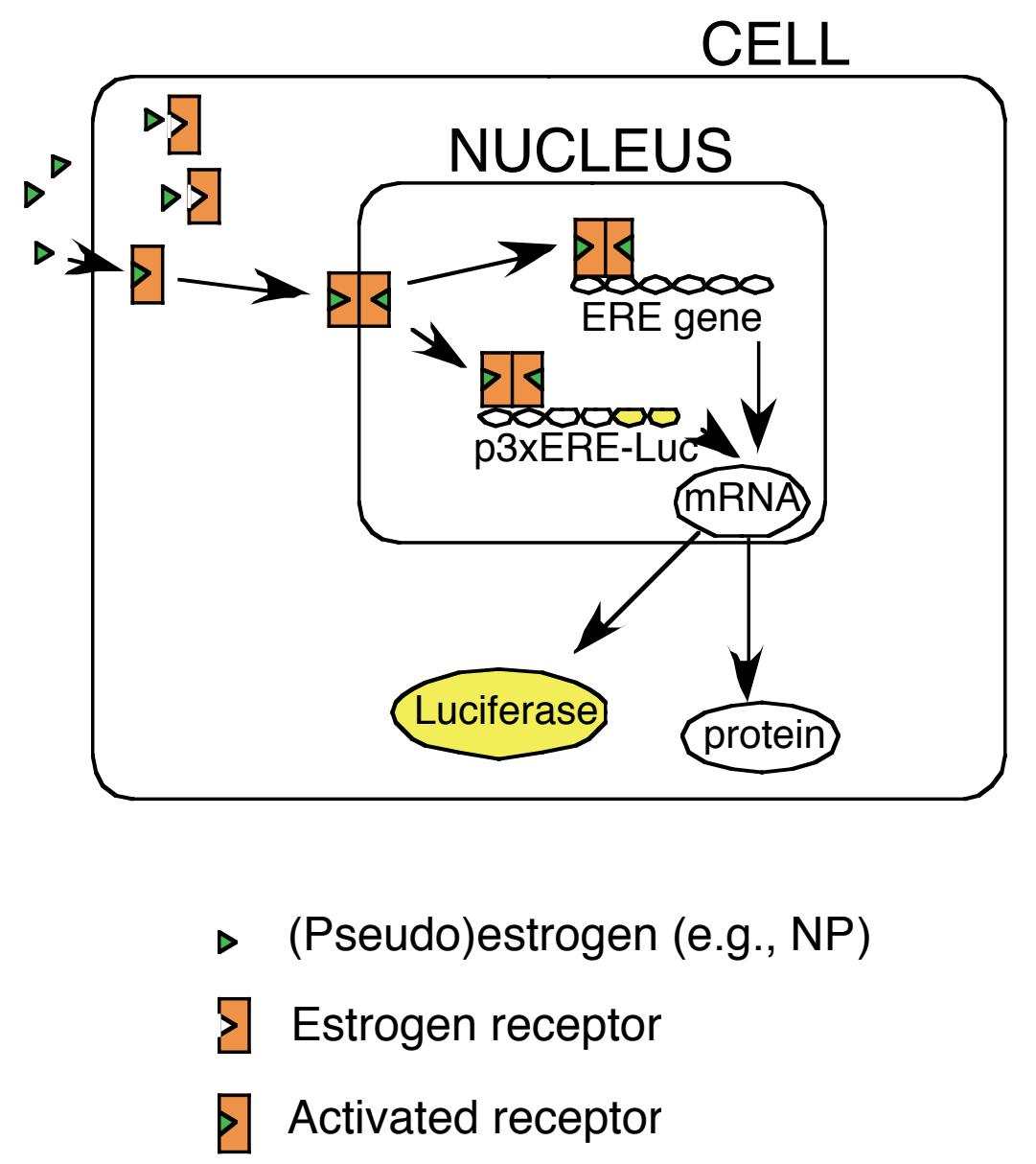

Figure 16. Schematic representation of operating principle of the estrogenic bioassay. Estrogen or 'estrogen mimics' bind to the estrogen receptor and are transported to the nucleus where they interact with estrogen response elements upstream of genes regulated by estrogenic compounds. Firefly luciferase, $l u c$, acts as a reporter gene for genes expressed under the control of estrogenic compounds. 


\section{ESTROGENIC BIOASSAY RESULTS}

Bioassay dose-response curves for $\mathrm{E}_{2}$ and NP are shown in Figure $17 \mathrm{~A}$ and $\mathrm{B}$, respectively. The values represent the fold increase in luminescence response (fold-induction) relative to the control without estrogenic compounds (which is set at 1). There is some irregular behavior in the dose-response curve although in general the fold-induction increases for increasing concentrations of $\mathrm{E}_{2}$ and NP.

A

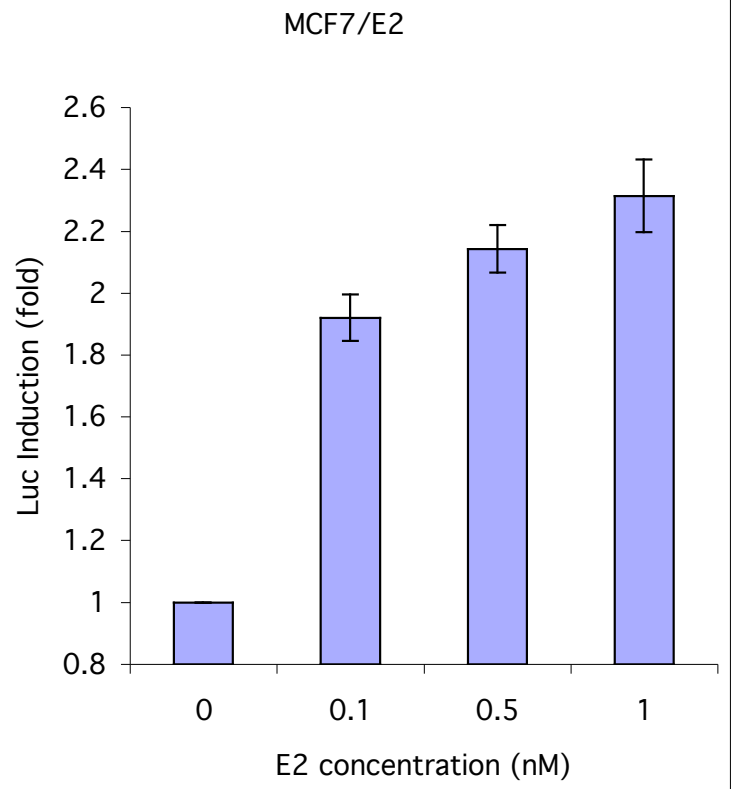

B

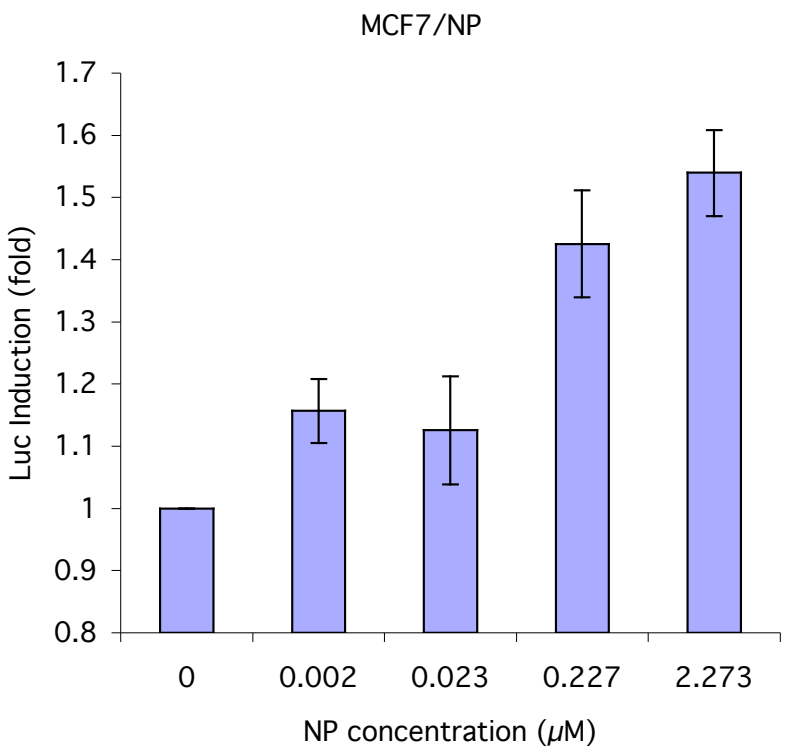

Figure 17. Luciferase reporter assay response to increasing concentrations of (A) 17 - -estradiol $\left(E_{2}\right)$ and $(B)$ NP. Results are means and standard deviations for eight replicate samples. Note differences in concentration range between the two plots.

The results for the estrogenic bioassay applied to both LPGC groundwater (wells 1P2 and 2J3) and LWRP effluent are shown in Figure 18. For the LWRP effluent samples, the level of fold-induction of luciferase was significantly higher than for the control (ca. 2.4-fold higher). Although NP concentration data were not obtained from the assayed samples due to inadequate sample volumes, the LWRP samples typically contain from $0.01-0.023 \square \mathrm{M} \mathrm{NP}(3 \square \mathrm{g} / \mathrm{L}$ on average; Table 8). The estrogenic response to LWRP samples exceeds that which would be due to the NP in the sample (ca. 1.4 fold induction for $0.023 \square \mathrm{M} \mathrm{NP}$ ), suggesting that other estrogenic compounds are present in the LWRP effluent. In contrast, the groundwater samples did not show a significant increase in luciferase activity relative to the control, which was consistent with analytical data showing no detectable NP or steroid estrogens in the groundwater samples. Although not statistically significant, the trend in slightly greater luciferase activity in the groundwater samples may be due to the presence of other unknown estrogenic compounds. Removal of chlorine by purging with $\mathrm{N}_{2}$ or pre-treating with thiosulfate increased the luciferase activity of the LWRP effluent, suggesting that chlorine (or related byproducts) reduce the cellular response to EDCs. The effect is likely due to cell toxicity (Lu et al., 2002) rather than 
any effect at the gene expression level. Apparently, the amount of thiosulfate added was not sufficient to neutralize the effect of chlorine in the LWRP sample. The LWRP samples that were $50 \%$ diluted showed roughly $50 \%$ of the luciferase activity of the undiluted samples, indicating that the assay accurately measures changes in estrogenic compound concentrations.

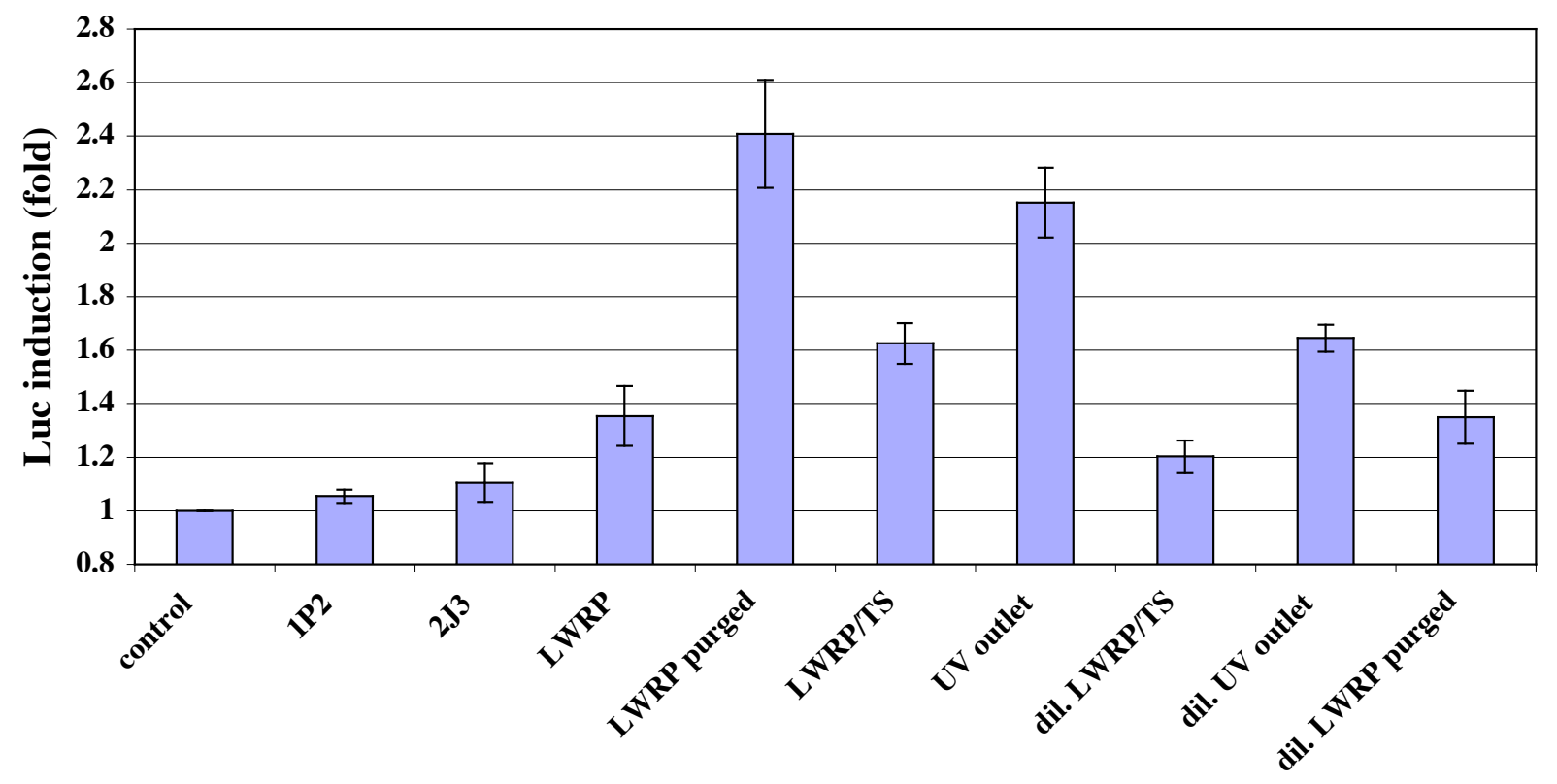

Figure 18. Estrogenic bioassay results for LWRP wastewater effluent and groundwater samples (1P2 and 2J3). LWRP effluent was treated to remove chlorine either by purging or addition of thiosulfate (TS). The UV outlet sample had no chlorine added. Dilutions (dil.) were 1:1 with medium.

\section{CONCLUSIONS AND SIGNIFICANCE}

- The Las Positas Golf Course in Livermore, CA is a hydrologically well-characterized site for studying the long-term occurrence, transport, and fate of EDCs originating from treated wastewater.

- Highly specific and sensitive analytical methods involving SPE and isotope dilution LC/MS/MS were successfully developed for a range of target compounds including NP, AP1EC, AP2EC, 17ฤ-estradiol, estrone, estrone 3-sulfate, and caffeine.

- Extraordinary precautions must be taken to avoid NP contamination artifacts during groundwater sampling. 
- NP was not detected in LPGC groundwater (detection limit, $11 \mathrm{ng} / \mathrm{L}$ ) despite average concentrations of $3000 \mathrm{ng} / \mathrm{L}$ in the irrigation water (i.e., LWRP tertiary-treated effluent); these results cannot be explained by low analytical recovery in groundwater samples, since recoveries were from 62 to $90 \%$ for the labeled NP internal standard. Maximum concentrations of the APEO metabolites AP1EC and AP2EC in LPGC groundwater were from 130- to 360-fold lower than in irrigation water. Since hydrological modeling indicates that irrigation water was diluted only 33 to $73 \%$ with local precipitation in the aquifer, attenuation of these compounds during transport through the vadose zone and saturated zone (e.g., by sorption of the APEO metabolites) must have been very substantial. High sorptive attenuation of NP is consistent with laboratory column studies and modeling conducted for this project.

- The estrogenic bioassay showed a significant response to the LWRP samples that contained approximately $3 \square g / L$ NP. No significant luciferase response was noted for cells exposed to LPGC groundwater, which was consistent with analytical data showing no detectable NP or steroid estrogens in the groundwater samples.

- To our knowledge, this is the first study of the subsurface transport of EDCs as a result of landscape irrigation with treated wastewater.

\section{REFERENCES}

Ahel, M., Giger, W., and M. Koch. 1994. Behavior of alkylphenol polyethoxylate surfactants in the aquatic environment - I. occurrence and transformation in sewage treatment. Water Research. 28:1131-1142.

Arnold, S. F., Klotz, D. M., Collins, B. M., Vonier, P. M., Guillette, Jr., L. J., and J. A. McLachlan. 1996a. Synergistic activation of estrogen receptor with combinations of environmental chemicals. Science. 272:1489-1493.

Bacaloni, A., Cavaliere, C., Faberi, A., Foglia, P., Samperi, R., and A. Lagana. 2005. Determination of isoflavones and coumestrol in river water and domestic wastewater sewage treatment plants. Analytica Chimica Acta. 531:229-237.

Benfenati, E., Barceló, D., Johnson, I., Galassi, S., and K. Levsen. 2003. Emerging organic contaminants in leachates from industrial waste landfills and industrial effluent. Trends in Analytical Chemistry. 22:757-765.

Blackburn, M. A. and M. J. Waldock. 1995. Concentrations of alkyphenols in rivers and estuaries in England and Wales. Water Research. 29:1623-1629.

Buerge, I. J., Poiger, T., Müller, M. D., and H.-R. Buser. 2003. Caffeine, an anthropogenic marker for wastewater contamination of surface waters. Environmental Science and Technology. 37:691-700. 
Burns, I. G. 1975. An equation to predict the leaching of surface-applied nitrate. Journal of Agricultural Science. 85:443-454.

Campbell, C. G., S. E. Borglin, F. B. Green, A. Grayson, E. Wozei, and W. T. Stringfellow. Submitted Environmental Monitoring, Fate, and Transport of Estrogenic Endocrine Disrupting Compounds: A Review.

Colborn, T., vom Saal, F. S. and A. M. Soto. 1993. Developmental effects of endocrine disrupting chemicals in wildlife and humans. Environmental Health Perspectives. 101:378-384.

Dallinga, J. W., Moonen, E. J. C., Dumoulin, J. C. M., Evers, J. L. H., Geraedts, J. P. M., and J.C.S. Kleinjans. 2002. Decreasing human semen quality and organochlorine compounds in blood. Human Reproduction. 17:1973-1979.

Fan, Y., Zhang, M., Da, S.-L., and Y.-Q. Feng. 2005. Determination of endocrine disruptors in environmental waters using poly(acrylamide-vinylpyridine) monolithic capillary for in-tube solid-phase microextraction coupled to high-performance liquid chromatography with fluorescence detection. Analyst. 130:1065-1069.

Field, J. A., and R. L. Reed. 1996. Nonylphenol polyethoxy carboxylate metabolites of nonionic surfactants in U.S. paper mill effluents, municipal sewage treatment plant effluents, and river waters. Environmental Science and Technology. 30:3544-3550.

Folmar, L.C., Hemmer, M. J., Denslow, N. D., Kroll, K., Chen, J., Cheek, A., Richman, H., Meredith, H. and E. G. Grau. 2002. A comparison of the estrogenic potencies of estradiol, ethynylestradiol, diethylstilbestrol, nonylphenol and methoxychlor in vivo and in vitro. Aquatic Toxicology. 60:101-110.

Fox, P., Houston, S., Westerhoff, P., Drewes, J. E., Nellor, M., Yanko, W., Baird, R., Rincon, M., Arnold, R., Lansey, K., Bassett, R., Gerba, C., Karpiscak, M., Quanrud, D., Amy, G., and M. Reinhard. 2001. An investigation of soil-aquifer treatment for sustainable water reuse. (publication release by the National Center for Sustainable Water Supply). Fry, D. M., and C. K. Toone, 1981. DDT-induced feminization of gull embryos. Science. 213:922-924.

Giesy, J. P., Hilscherova, K., Jones, P. D., Kannan, K., and M. Machala. 2002. Cell bioassays for detections of aryl hydrocarbon (AhR) and estrogen receptor (ER) mediated activity in environmental samples. Marine Pollution Bulletin. 45:3-16.

Guenther, K., Heinke, V., Thiele, B., Kleist, E., Prast, H., and T. Raecker. 2002. Endocrine disrupting nonylphenols are ubiquitous in food. Environmental Science and Technology. 36:1676-1680.

Guillette, L. J., Gross, T. S., Masson, G. R., Matter, J. M., Percival, H. F., and A. R. Woodward. 1994. Developmental abnormalities of the gonad and abnormal sex hormone concentrations in 
juvenile alligators from contaminated and control lakes in Florida. Environmental Health Perspectives. 102:680-687.

Hayes, T., Haston, K., Tsui, M., Hoang, A., Haeffele, C. and A. Yonk. 2002. Feminization of male frogs in the wild: water-borne herbicide threatens amphibian populations in parts of the United States. Nature. 419:895-896.

Heisterkamp, I., Ganrass, J., and W. Ruck. 2004. Bioassay-directed chemical analysis utilizing LC-MS: a tool for identifying estrogenic compounds in water samples? Analytical and Bioanalytical Chemistry. 378:709-715.

Howdeshell, K. L., Hotchkiss, A. K., Thayer, K. A., Vandenbergh, J. G., and F. S. vom Saal. 1999. Exposure to bisphenol A advances puberty. Nature. 401:763-764.

Huang, C. H. and D. L. Sedlak. 2001. Analysis of estrogenic hormones in municipal wastewater effluent and surface water using enzyme linked immunosorbent assay and gas chromatography/ tandem mass spectrometry. Environmental Toxicology and Chemistry. 20:133-139.

Itoh, N., Kayama, F., Tatsuki, T. J., and T. Tsukamoto. 2001. Have sperm counts deteriorated over the past 20 years in healthy, young Japanese men? Results from the Sapporo area. Journal of Andrology. 22:40-44.

Johnson, A. C., and J. P. Sumpter. 2001. Removal of endocrine-disrupting chemicals in activated sludge treatment works. Environmental Science and Technology. 35:4697-4703.

Johnson, M. L., Salveson, A., Holmes, L., Denison, M., and D. M. Fry. 1998. Environmental estrogens in agricultural drain water from the Central Valley of California. Bulletin of Environmental Contamination and Toxicology. 60:609-614.

Jury, W. A. 1982. Simulation of solute transport using a transfer function. Water Resource Research. 18:363.

Jury, W. A. and K. Roth. 1990. Transfer functions and solute movement through soil. Basel, Germany, Birkhauser Verlag.

Kolpin, D. W., Furlong, E. T., Meyer, M. T., Thurman, E. M., Zaugg, S. D., Barber, L. B., and H. T. Buxton. 2002. Pharmaceuticals, hormones, and other organic wastewater contaminants in U.S. streams, 1999-2000: a national reconnaissance. Environmental Science and Technology. 36:1202-1211.

Legler, J., van den Brink, C. E., Brouwer, A., Murk, A. J., van der Saag, P. T., Vethaak, A. D., and B. van der Burg. 1999. Development of a stably transfected estrogen receptor-mediated luciferase reporter gene assay in the human T47D breast cancer cell line. Toxicology Science. 48:55-66. 
Legler, J., Zeinstra, L. M., Schuitemaker, F., Lanser, P. H., Bogerd, J., Brouwer, A., Vethaak, A. D., DeVoogt, P., Murk, A. J., and B. Van der Burg. 2002a. Comparison of in vivo and in vitro reporter gene assays for short-term screening of estrogenic activity. Environmental Science and Technology. 36:4410-4415.

Levin, A. D. and T. Asano. 2004. Recovering sustainable water from wastewater. Environmental Science and Technology. 201A-208A.

Lu, W.Q., Chen, X. N., Yue, F., Jenter, C., Gminski, R., Li, X. Y., Xie, H., and MerschSundermann, V. 2002. Studies on the in vivo and in vitro mutagenicity and the lipid peroxidation of chlorinated surface (drinking) water in rats and metabolically competent human cells. Mutat. Res. 513:151-157.

McLachlan, J. A. (ed.) 1985. Estrogens in the Environment. Elsevier Publishing, New York.

Mocarelli, P., Brambilla, P., Geryhoux, P. M., Patterson, D. G., and L. L. Needham. 1996. Change in sex ratio with exposure to dioxin. Lancet. 348:409.

Müller, S.O. 2004. Xenoestrogens: mechanisms of action and detection methods. Analytical and Bioanalytical Chemistry. 378: 582-587.

NRC (National Resource Council). 1999. Hormonally active agents in the environment. National Academy Press, Washington, D. C.

Petrovic, M., and D. Barceló. 2000. Determination of anionic and nonionic surfactants, their degradation products, and endocrine-disrupting compounds in sewage sludge by liquid chromatography/mass spectrometry. Analytical Chemistry. 72:4560-4567

Petrovic, M., and D. Barceló. 2004. Analysis and fate of surfactants in sludge and sludgeamended soils. Trends in Analytical Chemistry. 23:762-771.

Petrovic, M., Eljarrat, E., Lopez de Alda, M. J. and D. Barceló. 2002. Recent advances in the mass spectrometric analysis related to endocrine disrupting compounds in aquatic environmental samples. Journal of Chromatography. 974:23-51.

Petrovic, M., Eljarrat, E., Lopez de Alda, M. J. and D. Barceló. 2004. Endocrine disrupting compounds and other emerging contaminants in the environment: a survey on new monitoring strategies and occurrence data. Analytical and Bioanalytical Chemistry. 378:549-562.

Petrovic, M., Gonzalez, S., and D. Barceló. 2003. Analysis and removal of emerging contaminants in wastewater and drinking water. Trends in Analytical Chemistry. 22:685-696.

Ramamoorthy, K., Wang, F., Chen, I. C., Safe, S., Norris, J. D., Mcdonnell, D. P., Gaido, K. W., Bocchinfuso,W. P. and K. S. Korach. 1997. Potency of combined estrogenic pesticides. Science. 275:405. 
Routledge, E. J., and J. P. Sumpter. 1996. Estrogenic activity of surfactants and some of their degradation products assessed using a recombinant yeast screen. Environmental Toxicology and Chemistry. 15:241-248.

Scotter, D. R., White, R. E., and J. S. Dyson. 1993. The Burns leaching equation. Journal of Soil Science. 44:25-33.

Seiler, R. L., Zaugg, S. D., Thomas, J. M., and D. L. Howcroft. 1999. Caffeine and pharmaceuticals as indicators of wastewater contamination in wells. Ground Water. 37:405-410.

Sharpe, R. M., and N. E. Skakkebaek. 1993. Are estrogens involved in falling sperm counts and disorders of the male reproductive tract? Lancet. 341:1392-1395.

Snyder, S. A, Westerhoff, P., Yoon, Y., and D. L. Sedlak. 2003. Pharmaceuticals, personal care products, and endocrine disruptors in water: implications for the water industry. Environmental Engineering Science. 20:449-469.

Soto, A. M., Sonnenschein, C., Chung, K. L., Fernandez, M. F., Olea, N., and F. O. Serrano. 1995. The E-SCREEN assay as a tool to identify estrogens: an update on estrogenic environmental pollutants. Environmental Health Perspectives. 103(Suppl.):113-122.

Standley, L. J., Kaplan, L. A., and D. Smith. 2000. Molecular tracers of organic matter sources to surface water resources. Environmental Science and Technology. 34:3124-3130.

Stopper, H., Schmitt, E., and K. Kobras. 2005. Genotoxicity of phytoestrogens. Mutation Research. 574:139-155.

Swan, S. H., Elkin, E. P., and L. Fenster. 1997. Have sperm densities declined? A reanalysis of global trend data. Environmental Health Perspectives. 105:1228-1232.

Ternes, T. A., Joss, A., and H. Siegrist. 2004. Scrutinizing pharmaceuticals and personal care products in wastewater treatment. Environmental Science and Technology. 393A-399A.

United States Environmental Protection Agency (US EPA). 1997. Special report on environmental endocrine disruption: an effects assessment and analysis. Washington, D. C: Office of Research and Development. EPA/630/R-96/012.

Westerhoff, P., Yeomin, Y., Snyder, S., and E. Wert. 2005. Fate of endocrine-disruptor pharmaceutical, and personal care product chemicals during simulated drinking water treatment processes. Environmental Science and Technology. 39:6649-6663.

White , R. E., Heng, L. K., and R. B. Edis.1998. Transfer function approaches to modeling solute transport in soils. Chapter 12. In H Magdi Selim and L Ma (eds.). Physical nonequilibrium in soils: modeling and application. Sleep Bear Press. Ann Arbor Press, Inc. Chelsea, MI. 311-347. 
Wozei, E. 2004. Investigating the reduction of estrogenic activity by activated sludge. Doctoral Thesis. University of California, Berkeley, 155.

Ying, G.-G., Williams, B. and R. Kookana. 2002. Environmental fate of alkyphenols and alkyphenol ethoxylates - a review. Environmental International. 28:215-226.

Zacharewski, T. 1997. In vitro bioassays for assessing estrogenic substances. Environmental Science and Technology. 31:613-623.

Zhang, F., Bartels, M. J., Brodeur, J. C., McClymont, E. L., and K. B. Woodburn. 2004. Quantitation of 17 alpha-ethinylestradiol in aquatic samples using liquid-liquid phase extraction, dansyl derivatization, and liquid chromatography/positive electrospray tandem mass spectrometry. Rapid Communications in Mass Spectrometry. 18:2739-2742. 